\title{
Reactions of ruthenium acetylide complexes with benzylidenemalonitrile $\uparrow$
}

\author{
Chao-Wan Chang, Ying-Chih Lin,* Gene-Hsiang Lee and Yu Wang \\ Department of Chemistry, National Taiwan University, Taipei, Taiwan 106, Republic of China. \\ E-mail:yclin@mail.ch.ntu.edu.tw
}

Received 19th July 1999, Accepted 18th October 1999

\begin{abstract}
Reactions of $\left[\mathrm{RuCp}(\mathrm{L})\left(\mathrm{L}^{\prime}\right)(\mathrm{C} \equiv \mathrm{CPh})\right]\left(\mathrm{Cp}=\eta^{5}-\mathrm{C}_{5} \mathrm{H}_{5} ; \mathrm{L}=\mathrm{PPh}_{3}, \mathrm{~L}^{\prime}=\mathrm{P}(\mathrm{OMe})_{3} \mathbf{1 a} ; \mathrm{LL}^{\prime}=\right.$ dppe $=\mathrm{Ph}_{2} \mathrm{PCH}_{2}-$ $\mathrm{CH}_{2} \mathrm{PPh}_{2} \mathbf{1 b} ; \mathrm{L}=\mathrm{PPh}_{3}, \mathrm{~L}^{\prime}=\mathrm{CN}^{t} \mathrm{Bu}$ 1c) with $\mathrm{H}(\mathrm{Ph}) \mathrm{C}=\mathrm{C}(\mathrm{CN})_{2}$ gave the cyclobutenyl complexes $[\mathrm{RuCp}(\mathrm{L})-$ $\left.\left(\mathrm{L}^{\prime}\right)\left\{\mathrm{C}=\mathrm{C}(\mathrm{Ph}) \mathrm{CH}(\mathrm{Ph}) \mathrm{C}(\mathrm{CN})_{2}\right\}\right] \mathbf{2 a}, \mathbf{2} \mathbf{b}$ and $\mathbf{2} \mathbf{c}$ which readily transform to the butadienyl complexes $\left[\mathrm{RuCp}(\mathrm{L})\left(\mathrm{L}^{\prime}\right)\left\{\mathrm{C}\left[=\mathrm{C}(\mathrm{CN})_{2}\right] \mathrm{C}(\mathrm{Ph}) \mathrm{CH}(\mathrm{Ph})\right\}\right]$ 3a, 3b and $\mathbf{3 c}$, respectively. Thermolysis of $\mathbf{3 a}$ in benzene afforded the allylic complex $\left[\mathrm{RuCp}\left\{\mathrm{P}(\mathrm{OMe})_{3}\right\}\left[\eta^{3}-\mathrm{C}\left[=\mathrm{C}(\mathrm{CN})_{2}\right] \mathrm{C}(\mathrm{Ph}) \mathrm{CH}(\mathrm{Ph})\right\}\right] 4$ in high yield. Reaction of 4 with ${ }^{t} \mathrm{BuNC}$ gave $\left[\mathrm{RuCp}\left\{\mathrm{P}(\mathrm{OMe})_{3}\right\}\left(\mathrm{CN}^{t} \mathrm{Bu}\right)\left[\eta^{1}-\mathrm{C}\left[=\mathrm{C}(\mathrm{CN})_{2}\right] \mathrm{C}(\mathrm{Ph}) \mathrm{CH}(\mathrm{Ph})\right\}\right]$ 5. Treatment of 1 a with $\mathrm{Cl}(\mathrm{Ph}) \mathrm{C}=\mathrm{C}(\mathrm{CN})_{2}$ afforded the neutral vinylidene phosphonate complex $\left[\mathrm{RuCp}\left(\mathrm{PPh}_{3}\right)\left\{\mathrm{P}(\mathrm{O})(\mathrm{OMe})_{2}\right\}\left\{=\mathrm{C}=\mathrm{C}(\mathrm{Ph}) \mathrm{C}(\mathrm{Ph}) \mathrm{C}(\mathrm{CN})_{2}\right\}\right]$ 6. Reactions of $\mathbf{1 b}$ and 1c, both lacking phosphite ligands, with $\mathrm{Cl}(\mathrm{Ph}) \mathrm{C}=\mathrm{C}(\mathrm{CN})_{2}$ gave the cationic vinylidene complexes $\left[\mathrm{RuCp}(\mathrm{L})\left(\mathrm{L}^{\prime}\right)\left\{=\mathrm{C}=\mathrm{C}(\mathrm{Ph}) \mathrm{C}(\mathrm{Ph}) \mathrm{C}(\mathrm{CN})_{2}\right\}\right]^{+} \mathbf{7 b}$ and $\mathbf{7 c}$, respectively. Treatment of $\mathbf{1 a}$ with $\mathrm{ICH}_{2} \mathrm{CN}$ afforded $\left[\mathrm{RuCp}\left(\mathrm{PPh}_{3}\right)\left\{\mathrm{P}(\mathrm{OMe})_{3}\right\}\left\{=\mathrm{C}=\mathrm{C}(\mathrm{Ph}) \mathrm{CH}_{2} \mathrm{CN}\right\}\right] \mathrm{I}$ 8a. In the presence of acid complex 8a decomposes to give the acyl complex $\left[\mathrm{RuCp}\left(\mathrm{PPh}_{3}\right)\left\{\mathrm{P}(\mathrm{OMe})_{3}\right\}\left(\mathrm{COCH}_{2} \mathrm{Ph}\right)\right]$ 10. The structures of $\mathbf{3 a}, \mathbf{4}, \mathbf{6}$ and the latter complex have been determined by single-crystal X-ray diffraction analysis.
\end{abstract}

\section{Introduction}

Chemical reactivities of metal acetylide complexes have been the focus of several recent works due to their wide applications in many areas of organometallic ${ }^{1}$ and material chemistry. ${ }^{2}$ The co-ordinated acetylide ligand on a transition metal is reactive toward electrophiles, undergoing either alkylation or protonation at the $\beta$-carbon to give a stable vinylidene complex. The cycloaddition of alkynes with isocyanates has been reported in nickel(0) complexes. ${ }^{3}$ This reaction possibly proceeds through a metallacycle formed by the $\sigma$-co-ordinated acetylide and isocyanate. One common reaction observed for the acetylide ligand is the $[2+2]$ cycloaddition of the triple bond with unsaturated organic substrates. ${ }^{4} \mathrm{~A}$ few cycloadditions of organic substrates such as $\mathrm{CS}_{2},{ }^{5}(\mathrm{NC})_{2} \mathrm{C}=\mathrm{C}\left(\mathrm{CF}_{3}\right)_{2},(\mathrm{NC})_{2} \mathrm{C}=$ $\mathrm{C}(\mathrm{CN})_{2}{ }^{6}$ and $\mathrm{Ph}_{2} \mathrm{C}=\mathrm{C}=\mathrm{O}^{7}$ to the acetylide ligand in various metal complexes have also been reported. Addition of activated alkenes containing an electron-withdrawing group to ruthenium acetylide complexes again resulted in a formal $[2+2]$ cycloaddition. This was followed by a facile ring opening of the resultant ruthenium cyclobutenyl complex generating the ruthenium butadienyl species. In some cases, subsequent displacement of a phosphine ligand led to the $\eta^{3}$-allylic product. For example, reactions between $\left[\mathrm{RuCp}(\mathrm{L})\left(\mathrm{L}^{\prime}\right)(\mathrm{C} \equiv \mathrm{CR})\right]$ $\left(\mathrm{R}=\mathrm{Me}\right.$ or $\mathrm{Ph} ; \mathrm{L}=\mathrm{PPh}_{3} ; \mathrm{L}^{\prime}=\mathrm{CO}, \mathrm{PPh}_{3}$ or $\mathrm{P}(\mathrm{OPh})_{3} ; \mathrm{LL}^{\prime}=$ dppe) and tetracyanoethylene gave cyclobutenyl [RuCp$\left.(\mathrm{L})\left(\mathrm{L}^{\prime}\right)\left\{\mathrm{C}=\mathrm{CRC}(\mathrm{CN})_{2} \mathrm{C}(\mathrm{CN})_{2}\right\}\right]$, butadienyl $\left[\mathrm{RuCp}(\mathrm{L})\left(\mathrm{L}^{\prime}\right)-\right.$ $\left.\left\{\mathrm{C}\left[=\mathrm{C}(\mathrm{CN})_{2}\right] \mathrm{CRC}=\mathrm{C}(\mathrm{CN})_{2}\right\}\right]$ and allylic $\left[\mathrm{RuCp}\left(\mathrm{PPh}_{3}\right)\left\{\eta^{3}-\right.\right.$ $\left.\mathrm{C}(\mathrm{CN})_{2} \mathrm{CRC}=\mathrm{C}(\mathrm{CN})_{2}\right\}$ ] complexes. $^{6}$

The stereochemical studies by Criegee and co-workers ${ }^{8}$ on the thermal ring opening of cis- and trans-1,2,3,4 tetramethylcyclobutenes were the first to show unambiguously the contrarotatory nature of the cyclobutene-butadiene electrocyclic interconversion. In 1965 Woodward and Hoffmann ${ }^{9}$ proposed a theory to rationalize such electrocyclic reactions.

† Supplementary data available: rotatable 3-D crystal structure diagram in CHIME format. See http://www.rsc.org/suppdata/dt/1999/4223/
Since then, Brauman and Golden ${ }^{10}$ have estimated that the thermally allowed contrarotatory process for cyclobutenes is more favored (by $15.0 \mathrm{kcal} \mathrm{mol}^{-1}$ ) than the disrotatory process. This experimental estimate is in accord with values obtained by Breulet and Schaefer ${ }^{11}$ from ab initio calculations.

Bruce and his co-workers studied the transformations of cycloadducts of transition metal acetylides and activated olefins, such as $\left.\mathrm{C}\left(\mathrm{CF}_{3}\right)_{2}=\mathrm{C}(\mathrm{CN})_{2}\right],{ }^{12}$ trans $-\mathrm{CH}\left(\mathrm{CO}_{2} \mathrm{Me}\right)=\mathrm{C}(\mathrm{CN})$ $\left(\mathrm{CO}_{2} \mathrm{Me}\right)^{13}$ and $4-\left(\mathrm{O}_{2} \mathrm{~N}\right) \mathrm{C}_{6} \mathrm{H}_{4} \mathrm{CH}=\mathrm{C}(\mathrm{CN}) \mathrm{R}\left(\mathrm{R}=\mathrm{CN}\right.$ or $\mathrm{CO}_{2-}^{-}$ $\mathrm{Et}){ }^{14}$ using a substrate that permitted the stereochemistry to be determined readily.

In a search for new chemical properties of the acetylide complexes, we carried out reactions of isocyanate and isothiocyanate with two such ruthenium complexes and recently reported ${ }^{15}$ sequential additions of the organic substrate to the acetylide producing a novel heterocyclic ligand not observed before. The $[2+2]$ cycloaddition is the first step and is followed by further additions of isothiocyanate to give a trimerization product. In this paper we report the reactions of $\mathrm{H}(\mathrm{Ph}) \mathrm{C}=$ $\mathrm{C}(\mathrm{CN})_{2}$ and $\mathrm{Cl}(\mathrm{Ph}) \mathrm{C}=\mathrm{C}(\mathrm{CN})_{2}$ with ruthenium acetylides. These olefins were chosen because the presence of different electrophilic groups might enable further information to be obtained in the course of these reactions.

\section{Results and discussion}

Synthesis of cyclobutenyl and butadienyl complexes

Treatment of $\left[\mathrm{RuCp}\left(\mathrm{PPh}_{3}\right)\left\{\mathrm{P}(\mathrm{OMe})_{3}\right\}(\mathrm{C} \equiv \mathrm{CPh})\right]$ 1a with $\mathrm{H}(\mathrm{Ph}) \mathrm{C}=\mathrm{C}(\mathrm{CN})_{2}$ in $\mathrm{CH}_{2} \mathrm{Cl}_{2}$ at room temperature for $1 \mathrm{~h}$ resulted in formation of a mixture of two complexes: $[\mathrm{RuCp}$ $\left.\left(\mathrm{PPh}_{3}\right)\left\{\mathrm{P}(\mathrm{OMe})_{3}\right\}\left\{\mathrm{C}=\mathrm{C}(\mathrm{Ph}) \mathrm{CH}(\mathrm{Ph}) \mathrm{C}(\mathrm{CN})_{2}\right\}\right]$ 2a and $[\mathrm{RuCp}-$ $\left.\left(\mathrm{PPh}_{3}\right)\left\{\mathrm{P}(\mathrm{OMe})_{3}\right\}\left\{\mathrm{C}\left[=\mathrm{C}(\mathrm{CN})_{2}\right] \mathrm{C}(\mathrm{Ph}) \mathrm{CH}(\mathrm{Ph})\right\}\right]$ 3a in a ratio of 1:1 (Scheme 1). Prolonging the reaction time did not alter the ratio. However, if we carried out this reaction at $0{ }^{\circ} \mathrm{C}$ for $3 \mathrm{~h}$ the ratio was about $2: 1$, which again changed to $1: 1$ at room temperature. Complexes 2a and 3a cannot be separated by column chromatography. Recrystallization of their mixture gave only 


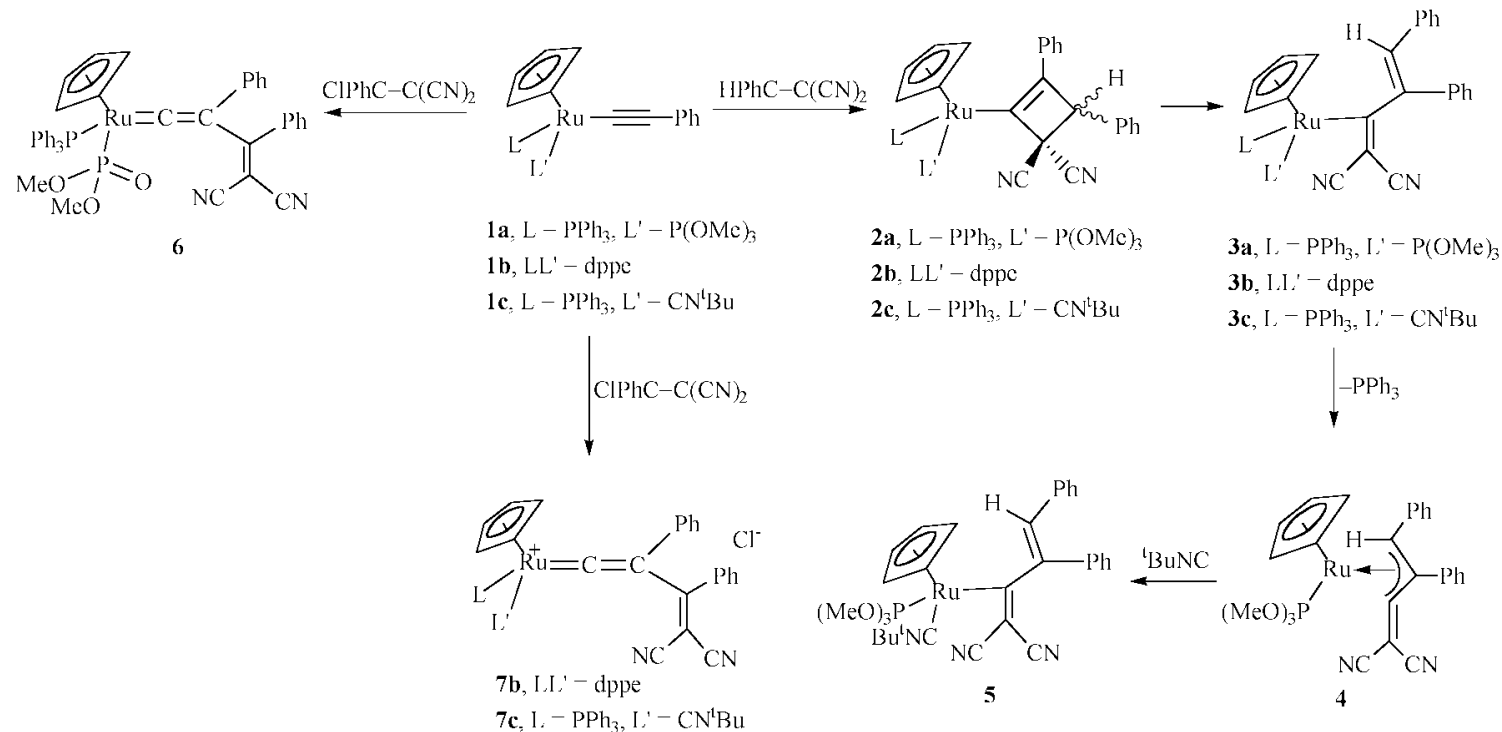

Scheme 1

single crystals of $\mathbf{3 a}$, which converted into the mixture in solution.

There was no obvious color change in the formation of complexes 2a and 3a from 1a, so the reaction was monitored by ${ }^{31} \mathrm{P}$ and ${ }^{1} \mathrm{H}$ NMR spectra. For 1a the ${ }^{31} \mathrm{P}$ NMR spectrum displays two doublet resonances at $\delta 56.2$ and 151.7 with $J_{\mathrm{P}-\mathrm{P}}=68.8 \mathrm{~Hz}$ assignable to $\mathrm{PPh}_{3}$ and $\mathrm{P}(\mathrm{OMe})_{3}$, respectively. Upon addition of 3 equivalents of $\mathrm{H}(\mathrm{Ph}) \mathrm{C}=\mathrm{C}(\mathrm{CN})_{2}$ to the $\mathrm{CDCl}_{3}$ solution of 1a, complexes 2a and 3a formed. The ${ }^{31} \mathrm{P}$ NMR spectrum of the mixture displays four doublet resonances of which the two at $\delta 58.8$ and 148.9 with $J_{\mathrm{P}-\mathrm{P}}=70.2 \mathrm{~Hz}$ are assigned to the $\mathrm{PPh}_{3}$ and $\mathrm{P}(\mathrm{OMe})_{3}$ of $\mathbf{2 a}$, respectively, and those at $\delta 58.3$ and 148.2 with $J_{\mathrm{P}-\mathrm{P}}=70.4 \mathrm{~Hz}$ to the corresponding ones of 3a. In the ${ }^{1} \mathrm{H}$ NMR spectrum two singlet resonances at $\delta 5.10$ and 5.01 and a doublet resonance at $\delta 3.27$ with $J_{\mathrm{H}-\mathrm{P}}=10.9 \mathrm{~Hz}$ are assigned to $\mathrm{CH}, \mathrm{Cp}$ and $\mathrm{OMe}$ of $\mathbf{2 a}$, respectively. The corresponding resonances for 3a appear at $\delta 4.66$ and 4.74 and 3.27 (doublet with $J_{\mathrm{H}-\mathrm{P}}=10.9 \mathrm{~Hz}$ ).

The reactions of complexes $1 \mathbf{b}$ and $\mathbf{1 c}$ with $\mathrm{H}(\mathrm{Ph}) \mathrm{C}=\mathrm{C}(\mathrm{CN})_{2}$ yielded kinetic and thermodynamic products. That of $\mathbf{1 b}$ in $\mathrm{CH}_{2} \mathrm{Cl}_{2}$ in $1 \mathrm{~h}$ at room temperature afforded $\mathbf{2 b}$ which transformed completely to $\mathbf{3 b}$ in $24 \mathrm{~h}$. For $\mathbf{2 b}$ the ${ }^{31} \mathrm{P}$ NMR spectrum displays two broad resonances at $\delta 98.1$ and 96.9 assignable to the dppe ligand and the ${ }^{1} \mathrm{H}$ NMR spectrum shows two singlet resonances at $\delta 5.24$ and 4.67 assignable to $\mathrm{CHPh}$ and $\mathrm{Cp}$, respectively. For $\mathbf{3 b}$ the ${ }^{31} \mathrm{P}$ NMR spectrum displays two broad resonances at $\delta 94.0$ and 92.3 and the ${ }^{1} \mathrm{H}$ NMR spectrum displays the broad resonance at $\delta 5.95$ assignable to $\mathrm{CHPh}$ and the resonance at $\delta 4.43$ to $\mathrm{Cp}$. Treatment of $1 \mathrm{c}$ with $\mathrm{H}(\mathrm{Ph}) \mathrm{C}=$ $\mathrm{C}(\mathrm{CN})_{2}$ in $\mathrm{CH}_{2} \mathrm{Cl}_{2}$ at room temperature for $10 \mathrm{~min}$ afforded $2 \mathrm{c}$ in $87 \%$ yield (Scheme 1). If $\mathbf{2 c}$ was not isolated immediately the ring-opening reaction proceeded and $\mathbf{3 c}$ formed. Attempts to recrystallize $\mathbf{2 b}$ and $\mathbf{2 c}$ from $\mathrm{CH}_{2} \mathrm{Cl}_{2}$-hexane $(1: 2)$ at $-20{ }^{\circ} \mathrm{C}$ resulted in isolation of $\mathbf{3 b}$ and $\mathbf{3 c}$, respectively. Complexes $\mathbf{2 a}$ and 3a containing $\mathrm{PPh}_{3}$ and $\mathrm{P}(\mathrm{OMe})_{3}$ as their ancillary ligands are in equilibrium. However, no such phenomenon was observed for complexes $\mathbf{2} \mathbf{b} / \mathbf{3 b}$ and $\mathbf{2 c / 3 \mathbf { c }}$ possibly because there is no $\mathrm{P}(\mathrm{OMe})_{3}$ ligand in them.

The molecular structure of complex 3a has been determined by a single-crystal X-ray diffraction analysis, an ORTEP ${ }^{16}$ drawing being shown in Fig. 1. Selected bond distances and angles are listed in Table 1. The co-ordination about the ruthenium is a distorted piano-stool geometry with the $\eta^{5}-\mathrm{C}_{5} \mathrm{H}_{5}$ group being symmetrically attached to the metal. All $\mathrm{Ru}-\mathrm{C}$ (Cp) bond distances range within 2.231(2)-2.249(2) ^ with an average of $2.238 \AA$. The $\mathrm{Ru}-\mathrm{C} 1$ bond distance of $2.055(8) \AA$ is relatively shorter. The butadienyl ligand is non-planar and there
Table 1 Selected bond distances $(\AA)$ and angles $\left({ }^{\circ}\right)$ of $\left[\mathrm{RuCp}\left(\mathrm{PPh}_{3}\right)\right.$ $\left.\left\{\mathrm{P}(\mathrm{OMe})_{3}\right\}\left\{\mathrm{C}\left[=\mathrm{C}(\mathrm{CN})_{2}\right] \mathrm{C}(\mathrm{Ph})=\mathrm{CH}(\mathrm{Ph})\right\}\right]$ 3a

\begin{tabular}{llll}
\hline $\mathrm{Ru}-\mathrm{P} 1$ & $2.2364(23)$ & $\mathrm{Ru}-\mathrm{P} 2$ & $2.3305(23)$ \\
$\mathrm{Ru}-\mathrm{C} 1$ & $2.055(8)$ & $\mathrm{C} 1-\mathrm{C} 16$ & $1.384(11)$ \\
$\mathrm{C} 1-\mathrm{C} 2$ & $1.506(11)$ & $\mathrm{C} 2-\mathrm{C} 3$ & $1.319(11)$ \\
$\mathrm{C} 2-\mathrm{C} 10$ & $1.512(11)$ & $\mathrm{C} 3-\mathrm{C} 4$ & $1.455(11)$ \\
$\mathrm{C} 16-\mathrm{C} 17$ & $1.428(11)$ & $\mathrm{C} 16-\mathrm{C} 18$ & $1.451(11)$ \\
$\mathrm{C} 17-\mathrm{N} 1$ & $1.143(11)$ & $\mathrm{C} 18-\mathrm{N} 2$ & $1.131(11)$ \\
& & & \\
$\mathrm{P} 1-\mathrm{Ru}-\mathrm{P} 2$ & $92.33(8)$ & $\mathrm{P} 1-\mathrm{Ru}-\mathrm{C} 1$ & $92.92(22)$ \\
$\mathrm{P} 2-\mathrm{Ru}-\mathrm{C} 1$ & $94.57(21)$ & $\mathrm{Ru}-\mathrm{C} 1-\mathrm{C} 16$ & $126.1(6)$ \\
$\mathrm{Ru}-\mathrm{C} 1-\mathrm{C} 2$ & $122.2(5)$ & $\mathrm{C} 1-\mathrm{C} 2-\mathrm{C} 10$ & $111.8(6)$ \\
$\mathrm{C} 1-\mathrm{C} 2-\mathrm{C} 3$ & $124.2(7)$ & $\mathrm{C} 3-\mathrm{C} 2-\mathrm{C} 10$ & $123.9(7)$ \\
\hline
\end{tabular}

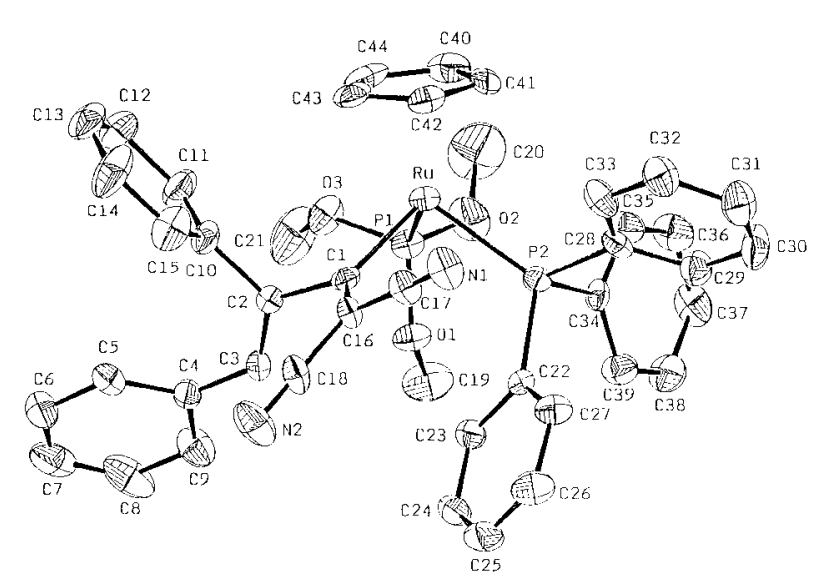

Fig. 1 An ORTEP drawing of complex 3a with thermal ellipsoids, (in all Figures) shown at the $30 \%$ probability level.

is no obvious delocalization between $\mathrm{C}-\mathrm{C}$ single and $\mathrm{C}=\mathrm{C}$ double bonds (C1-C16 1.384; C1-C2 1.506; C2-C3 1.319 ̊̊).

\section{Synthesis and structure of $\left[\mathrm{RuCp}\left\{\mathrm{P}(\mathrm{OMe})_{3}\right\}\left\{\eta^{3}-\mathrm{C}\left[=\mathrm{C}(\mathrm{CN})_{2}\right]-\right.\right.$ $\mathrm{C}(\mathrm{Ph}) \mathrm{CH}(\mathrm{Ph})\}] 4$}

Thermolysis of complex 3a in benzene at refluxing temperature for $2 \mathrm{~d}$ afforded the allylic complex $\left[\mathrm{RuCp}\left\{\mathrm{P}(\mathrm{OMe})_{3}\right\}\left\{\eta^{3}-\right.\right.$ $\left.\left.\mathrm{C}\left[=\mathrm{C}(\mathrm{CN})_{2}\right] \mathrm{C}(\mathrm{Ph}) \mathrm{CH}(\mathrm{Ph})\right\}\right] 4$ by removal of a $\mathrm{PPh}_{3}$ ligand with high yield (Scheme 1). The ${ }^{1} \mathrm{H}$ NMR spectrum of $\mathbf{4}$ displays a singlet resonance at $\delta 4.94$ and two doublet resonances at $\delta 3.63$ $\left(J_{\mathrm{H}-\mathrm{P}}=11.8\right)$ and $3.43\left(J_{\mathrm{H}-\mathrm{P}}=12.3 \mathrm{~Hz}\right)$ attributed to $\mathrm{Cp}, \mathrm{OMe}$ and $\mathrm{CH}(\mathrm{Ph})$, respectively. The ${ }^{31} \mathrm{P}$ NMR spectrum displays a singlet resonance at $\delta 159.35$ attributed to the $\mathrm{P}(\mathrm{OMe})_{3}$ ligand. 
Table 2 Selected bond distances $(\AA)$ and angles $\left(^{\circ}\right)$ of $[\mathrm{RuCp}$ $\left.\left\{\mathrm{P}(\mathrm{OMe})_{3}\right\}\left\{\eta^{3}-\mathrm{C}(\mathrm{CN})_{2} \mathrm{C}(\mathrm{Ph}) \mathrm{C}=\mathrm{CH}(\mathrm{Ph})\right\}\right] 4$

\begin{tabular}{llll}
\hline $\mathrm{Ru}-\mathrm{P}$ & $2.245(3)$ & $\mathrm{Ru}-\mathrm{C} 1$ & $2.250(9)$ \\
$\mathrm{Ru}-\mathrm{C} 2$ & $2.142(10)$ & $\mathrm{Ru}-\mathrm{C} 3$ & $1.934(10)$ \\
$\mathrm{C} 1-\mathrm{C} 2$ & $1.422(14)$ & $\mathrm{C} 2-\mathrm{C} 3$ & $1.418(13)$ \\
$\mathrm{C} 3-\mathrm{C} 4$ & $1.382(13)$ & $\mathrm{C} 4-\mathrm{C} 5$ & $1.439(14)$ \\
$\mathrm{C} 4-\mathrm{C} 6$ & $1.399(14)$ & $\mathrm{C} 5-\mathrm{N} 1$ & $1.124(13)$ \\
$\mathrm{C} 6-\mathrm{N} 2$ & $1.135(14)$ & & \\
& & & \\
$\mathrm{P}-\mathrm{Ru}-\mathrm{C} 1$ & $80.7(3)$ & $\mathrm{P}-\mathrm{Ru}-\mathrm{C} 2$ & $104.3(3)$ \\
$\mathrm{P}-\mathrm{Ru}-\mathrm{C} 3$ & $89.3(3)$ & $\mathrm{C} 1-\mathrm{C} 2-\mathrm{C} 3$ & $111.1(9)$ \\
$\mathrm{C} 1-\mathrm{C} 2-\mathrm{C} 13$ & $128.8(8)$ & $\mathrm{C} 3-\mathrm{C} 2-\mathrm{C} 13$ & $120.0(9)$ \\
$\mathrm{Ru}-\mathrm{C} 3-\mathrm{C} 4$ & $144.8(7)$ & $\mathrm{C} 3-\mathrm{C} 4-\mathrm{C} 5$ & $120.6(9)$ \\
$\mathrm{C} 3-\mathrm{C} 4-\mathrm{C} 6$ & $122.7(9)$ & $\mathrm{Ru}-\mathrm{C} 1-\mathrm{C} 2$ & $67.0(5)$ \\
$\mathrm{Ru}-\mathrm{C} 1-\mathrm{C} 7$ & $118.5(6)$ & & \\
\hline
\end{tabular}

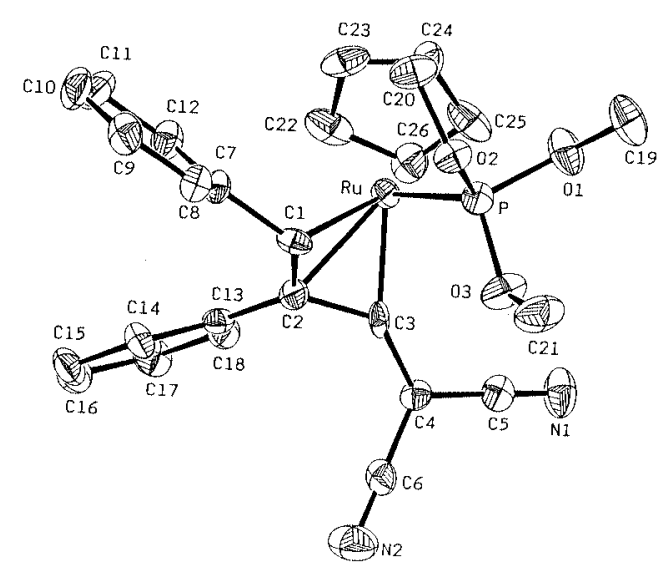

Fig. 2 An ORTEP drawing of complex 4.

No similar reaction was observed for $\mathbf{3 b}$ or $\mathbf{3 c}$. The weak bonding of the $\mathrm{PPh}_{3}$ ligand in $\mathbf{3 a}$ could possibly be owing to the presence of the $\mathrm{P}(\mathrm{OMe})_{3}$ ligand. The $\mathrm{Ru}-\mathrm{P}$ bonds in $\mathbf{3 b}$ and $\mathbf{3 c}$ should be relatively stronger.

The structure of complex $\mathbf{4}$ has been determined by a singlecrystal X-ray diffraction analysis. An ORTEP drawing is shown in Fig. 2. Selected bond distances and angles are listed in Table 2. The co-ordination sphere consists of a $\eta^{5}-\mathrm{C}_{5} \mathrm{H}_{5}$ group $(\mathrm{Ru}-$ $\mathrm{C}(\mathrm{Cp}) 2.183-2.253 \AA$, average $2.214 \AA$ ), a $\mathrm{P}(\mathrm{OMe})_{3}$ ligand $(\mathrm{Ru}-$ P 2.245(3) $\AA$ ) and a $\eta^{3}$-allylic ligand (Ru-C1 2.250(9), Ru-C2 2.142(10), Ru-C3 1.934(10) $\AA$ ). The $\eta^{3}$-allylic ligand is formed by co-ordination of the $\mathrm{C} 1-\mathrm{C} 2$ bond of the butadienyl ligand and there is delocalization between $\mathrm{C}-\mathrm{C}$ single and $\mathrm{C}=\mathrm{C}$ double bonds (C2-C3 1.418(13); C1-C2 1.422(14); C3-C4 1.382(13) A).

Reaction of complex 4 with ${ }^{t} \mathrm{BuNC}$ in $\mathrm{CH}_{2} \mathrm{Cl}_{2}$ at refluxing temperature for $2 \mathrm{~d}$ afforded the butadienyl complex [RuCp$\left.\left\{\mathrm{P}(\mathrm{OMe})_{3}\right\}\left(\mathrm{CN}^{t} \mathrm{Bu}\right)\left\{\mathrm{C}\left[=\mathrm{C}(\mathrm{CN})_{2}\right] \mathrm{C}(\mathrm{Ph}) \mathrm{CH}(\mathrm{Ph})\right\}\right]$ 5. The ${ }^{31} \mathrm{P}$ NMR spectrum displays a singlet resonance at $\delta 159.2$ assignable to the $\mathrm{P}(\mathrm{OMe})_{3}$ ligand. The ${ }^{1} \mathrm{H}$ NMR spectrum displays three singlet resonances at $\delta 5.97,4.63$ and 1.34 assignable to $\mathrm{CHPh}, \mathrm{Cp}$ and $\mathrm{C}\left(\mathrm{CH}_{3}\right)_{3}$, respectively, and a doublet resonance at $\delta 3.57$ with $J_{\mathrm{H}-\mathrm{P}}=11.6 \mathrm{~Hz}$ assignable to $\mathrm{P}(\mathrm{OMe})_{3}$. The $\eta^{3}$ allylic ligand in $\mathbf{4}$ became $\eta^{1}$ bonding and the co-ordination site was replaced by a donor tert-butyl cyanide ligand. Complex $\mathbf{5}$ is thermally more stable than $\mathbf{3 b}$ and $\mathbf{3 c}$. Thermolysis of complex 5 in benzene at refluxing temperature for two days did not remove the phosphite or the isocyanide ligand.

\section{Reaction of ruthenium acetylides with $\mathrm{Cl}(\mathrm{Ph}) \mathrm{C}=\mathrm{C}(\mathrm{CN})_{2}$}

Metal acetylide complexes are known to react readily with activated olefins containing electron-withdrawing groups affording $[2+2]$ cycloaddition products. We therefore treated vinyl chloride with the acetylide complex 1a to see if the reaction would proceed in a similar manner. The reaction of $\mathbf{1 a}$ with an excess of $\mathrm{Cl}(\mathrm{Ph}) \mathrm{C}=\mathrm{C}(\mathrm{CN})_{2}$ in $\mathrm{CH}_{2} \mathrm{Cl}_{2}$ at room temperature for $24 \mathrm{~h}$
Table 3 Selected bond distances $(\AA)$ and angles $\left({ }^{\circ}\right)$ of $[\mathrm{RuCp}-$ $\left.\left(\mathrm{PPh}_{3}\right)\left\{\mathrm{P}(\mathrm{O})(\mathrm{OMe})_{2}\right\}\left\{\mathrm{C}=\mathrm{C}(\mathrm{Ph}) \mathrm{C}(\mathrm{Ph}) \mathrm{C}(\mathrm{CN})_{2}\right\}\right] \cdot(\mathrm{OH})(\mathrm{Ph}) \mathrm{C}=\mathrm{C}(\mathrm{CN})_{2} 6$

\begin{tabular}{llll}
\hline $\mathrm{Ru}-\mathrm{P} 1$ & $2.3437(14)$ & $\mathrm{Ru}-\mathrm{P} 2$ & $2.2965(16)$ \\
$\mathrm{Ru}-\mathrm{C} 1$ & $1.790(5)$ & $\mathrm{C} 1-\mathrm{C} 2$ & $1.362(6)$ \\
$\mathrm{C} 2-\mathrm{C} 3$ & $1.434(7)$ & $\mathrm{C} 2-\mathrm{C} 5$ & $1.501(7)$ \\
$\mathrm{C} 3-\mathrm{C} 4$ & $1.373(7)$ & $\mathrm{C} 4-\mathrm{C} 17$ & $1.447(8)$ \\
$\mathrm{C} 4-\mathrm{C} 18$ & $1.492(7)$ & $\mathrm{O} 1-\mathrm{H}$ & $1.00(5)$ \\
$\mathrm{O} 4-\mathrm{H}$ & $1.45(5)$ & $\mathrm{C} 17-\mathrm{N} 1$ & $1.143(8)$ \\
$\mathrm{C} 18-\mathrm{N} 2$ & $1.136(7)$ & $\mathrm{P} 2-\mathrm{O} 1$ & $1.475(3)$ \\
$\mathrm{P} 2-\mathrm{O} 2$ & $1.593(4)$ & $\mathrm{P} 2-\mathrm{O} 3$ & $1.585(3)$ \\
& & & \\
$\mathrm{P} 1-\mathrm{Ru}-\mathrm{P} 2$ & $92.01(5)$ & $\mathrm{P} 1-\mathrm{Ru}-\mathrm{C} 1$ & $95.85(14)$ \\
$\mathrm{Ru}-\mathrm{C} 1-\mathrm{C} 2$ & $173.9(4)$ & $\mathrm{C} 1-\mathrm{C} 2-\mathrm{C} 3$ & $120.4(4)$ \\
$\mathrm{C} 2-\mathrm{C} 3-\mathrm{C} 4$ & $123.5(4)$ & $\mathrm{C} 3-\mathrm{C} 4-\mathrm{C} 17$ & $124.7(5)$ \\
$\mathrm{C} 3-\mathrm{C} 4-\mathrm{C} 18$ & $122.6(5)$ & $\mathrm{P} 2-\mathrm{O} 1-\mathrm{H}$ & $171(3)$ \\
\hline
\end{tabular}

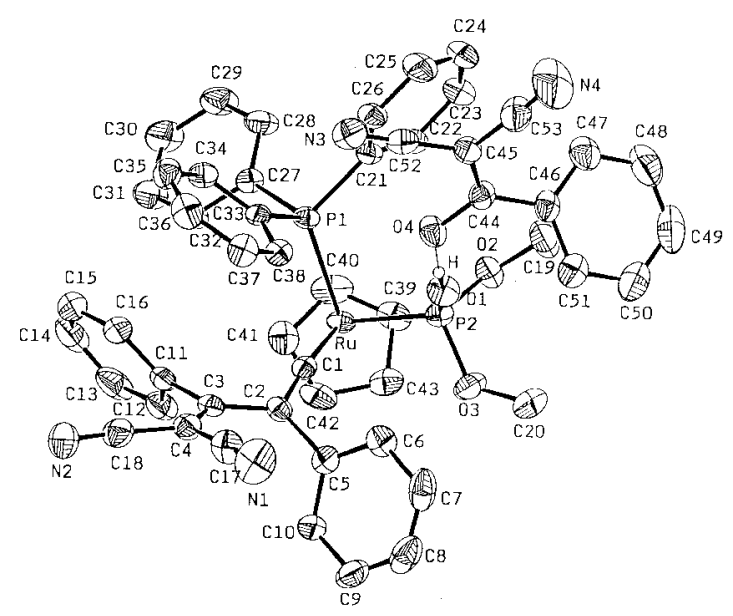

Fig. 3 An ORTEP drawing of complex 6.

gave an orange-red solution from which the neutral vinylidene complex $\left[\mathrm{RuCp}\left(\mathrm{PPh}_{3}\right)\left\{\mathrm{P}(\mathrm{O})(\mathrm{OMe})_{2}\right\}\{=\mathrm{C}=\mathrm{C}(\mathrm{Ph}) \mathrm{C}(\mathrm{Ph})-\right.$ $\left.\left.\mathrm{C}(\mathrm{CN})_{2}\right\}\right] 6$ was obtained in $88 \%$ yield. The ${ }^{1} \mathrm{H}$ NMR spectrum displays inequivalent $\mathrm{OMe}$ resonances at $\delta 3.20$ and 2.96 both with $J_{\mathrm{H}-\mathrm{P}}=11.6 \mathrm{~Hz}$. Two doublet ${ }^{31} \mathrm{P}$ resonances appear at $\delta 105.6$ and 43.7 with $J_{\mathrm{P}-\mathrm{P}}=47.8 \mathrm{~Hz}$, the former shifted significantly from $\delta 158.3$ of $\mathrm{P}(\mathrm{OMe})_{3}$ in $1 \mathrm{a}$ indicating that an Arbuzov-like dealkylation ${ }^{16}$ of the $\mathrm{P}(\mathrm{OMe})_{3}$ ligand could have occurred in the reaction. The ${ }^{13} \mathrm{C}$ NMR spectrum displays a doublet of doublet resonance at $\delta 339.8$ attributed to $\mathrm{C}_{\alpha}$, indicating the presence of a vinylidene ligand. The product is thus assumed to have a neutral vinylidene structure and a phosphonate ligand.

Evaporation of the solvent of the crude product caused formation of orange crystals. Complex 6 cocrystallized with $(\mathrm{OH})(\mathrm{Ph}) \mathrm{C}=\mathrm{C}(\mathrm{CN})_{2}$, a product resulting from substitution of the chlorine atom of excess of $\mathrm{Cl}(\mathrm{Ph}) \mathrm{C}=\mathrm{C}(\mathrm{CN})_{2}$. The structure of $\mathbf{6}$ was fully characterized by a single-crystal X-ray diffraction analysis. An ORTEP drawing is shown in Fig. 3. Selected bond distances and angles are listed in Table 3. The short $\mathrm{Ru}-\mathrm{Cl}$ bond of $1.790(5) \AA$ is typical of a ruthenium vinylidene system and so is the $\mathrm{C} 1-\mathrm{C} 2$ bond of $1.362(6) \AA .^{18}$ The rutheniumvinylidene linkage is nearly linear; the bond angle $\mathrm{Ru}-\mathrm{C} 1-\mathrm{C} 2$ is $173.9(4)^{\circ}$. The relatively short bond length P2-O1 (1.475(3) Å) with no methyl group bound to $\mathrm{O} 1$ indicates the presence of a phosphonate ligand. The bonds $\mathrm{P} 2-\mathrm{O} 2$ and $\mathrm{P} 2-\mathrm{O} 3$ (1.593(4) and 1.585(3) $\AA$ ) are relatively longer. There is an intermolecular hydrogen bond between the phosphonate ligand of $\mathbf{6}$ and $(\mathrm{OH})(\mathrm{Ph}) \mathrm{C}=\mathrm{C}(\mathrm{CN})_{2}$ with $\mathrm{O} 1-\mathrm{H}$ and $\mathrm{O} 4-\mathrm{H} 1.00(5)$ and $1.45(5)$ $\AA$, respectively.

Lacking phosphite ligands, both complexes $\mathbf{1 b}$ and $\mathbf{1 c}$, upon reacting with $\mathrm{Cl}(\mathrm{Ph}) \mathrm{C}=\mathrm{C}(\mathrm{CN})_{2}$, afforded in high yield the cationic vinylidene complexes $\left[\mathrm{RuCp}(\mathrm{L})\left(\mathrm{L}^{\prime}\right)\{=\mathrm{C}=\mathrm{C}(\mathrm{Ph}) \mathrm{C}(\mathrm{Ph})-\right.$ $\left.\left.\mathrm{C}(\mathrm{CN})_{2}\right\}\right] \mathrm{Cl} 7 \mathbf{b},\left(\mathrm{LL}^{\prime}=\mathrm{dppe}\right)$ and $7 \mathbf{c},\left(\mathrm{L}=\mathrm{PPh}_{3}, \mathrm{~L}^{\prime}=\mathrm{CN}^{t} \mathrm{Bu}\right)$, respectively. For $\mathbf{7 b}$ the ${ }^{31} \mathrm{P}$ NMR spectrum displays a singlet 
resonance at $\delta 77.4$ assignable to the dppe ligand. In the ${ }^{13} \mathrm{C}$ NMR spectrum the triplet resonance at $\delta 351.8$ with $J_{\mathrm{C}-\mathrm{P}}=14.8$ $\mathrm{Hz}$ is assigned to $\mathrm{C}_{\alpha}$. The ${ }^{1} \mathrm{H}$ NMR spectrum of $7 \mathbf{c}$ displays resonances at $\delta 5.66$ and 1.17 attributed to $\mathrm{Cp}$ and $\mathrm{C}\left(\mathrm{CH}_{3}\right)_{3}$, respectively, and the ${ }^{31} \mathrm{P}$ NMR spectrum displays a singlet resonance at $\delta 44.1$ assignable to the $\mathrm{PPh}_{3}$ ligand. The ${ }^{13} \mathrm{C}$ NMR spectrum displays a doublet resonance at $\delta 345.2$ with $J_{\mathrm{C}-\mathrm{P}}=12.0 \mathrm{~Hz}$ assignable to $\mathrm{C}_{\alpha}$ of the vinylidene ligand and a doublet resonance at $\delta 198.6$ with $J_{\mathrm{C}-\mathrm{P}}=16.3 \mathrm{~Hz}$ assignable to the $C \mathrm{~N}^{t} \mathrm{Bu}$. It is not surprising that the chloride atom of $\mathrm{Cl}(\mathrm{Ph}) \mathrm{C}=\mathrm{C}(\mathrm{CN})_{2}$ behaved as a good leaving group and ended up as a counter anion after the formation of the cationic vinylidene complexes; $\mathrm{NH}_{4} \mathrm{PF}_{6}$ was added to exchange the counter anion after the reaction was completed.

\section{Other phosphonate vinylidene complexes}

Treatment of complex 1a with $\mathrm{ICH}_{2} \mathrm{CN}$ in $\mathrm{CH}_{2} \mathrm{Cl}_{2}$ for $10 \mathrm{~min}$ afforded the vinylidene complex $\left[\mathrm{RuCp}\left(\mathrm{PPh}_{3}\right)\left\{\mathrm{P}(\mathrm{OMe})_{3}\right\}=\right.$ $\left.\left.\mathrm{C}=\mathrm{C}(\mathrm{Ph}) \mathrm{CH}_{2} \mathrm{CN}\right\}\right] \mathrm{I} \mathbf{8 a}$ in $64.8 \%$ yield (Scheme 2). In the ${ }^{1} \mathrm{H}$

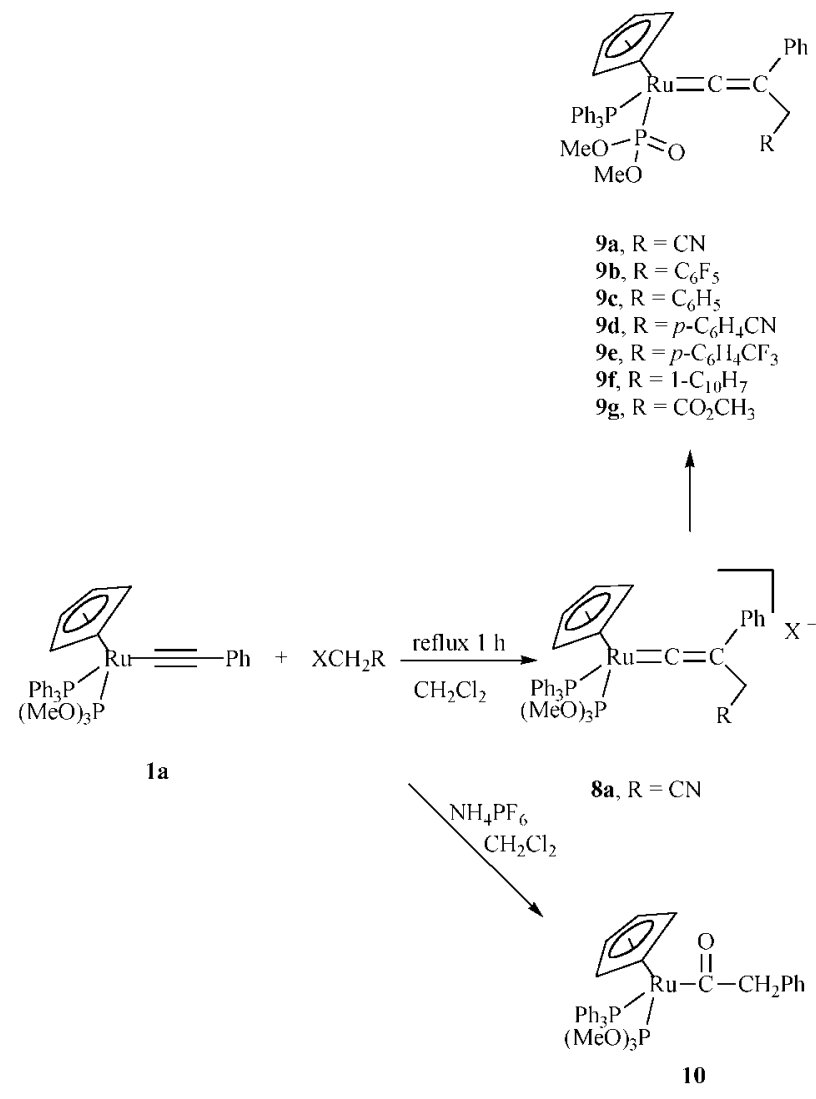

Scheme 2

NMR spectrum the two dd resonances at $\delta 3.27$ and 3.17 are assigned to the two non-equivalent methylene protons. Lengthening the reaction time caused Arbuzov-like dealkylation to occur, leading to formation of the phosphonate complex [RuCp$\left.\left(\mathrm{PPh}_{3}\right)\left\{\mathrm{P}(\mathrm{O})(\mathrm{OMe})_{2}\right\}\left\{=\mathrm{C}=\mathrm{C}(\mathrm{Ph}) \mathrm{CH}_{2} \mathrm{CN}\right\}\right]$ 9a. Transformation of the phosphite ligand to a phosphonate ligand was revealed by a significant shift of the ${ }^{31} \mathrm{P}$ NMR resonance from $\delta 135.3$ to 95.4. Formation of $\mathrm{CH}_{3} \mathrm{I}$ was seen in the ${ }^{1} \mathrm{H}$ NMR spectrum. The observation of the sequential transformation seems to indicate that formation of the phosphonate ligand required halide ion. The most characteristic spectroscopic data of the two vinylidene complexes consist of a strongly deshielded $\mathrm{C}_{\alpha}$ resonance as a doublet of doublet at $\delta 348.6 \pm 2.5$ in the ${ }^{13} \mathrm{C}$ NMR spectrum. ${ }^{19}$ Since $\mathbf{8 a}$ is a cationic complex containing a $\mathrm{P}(\mathrm{OMe})_{3}$ ligand, it is not surprising to see an Arbuzov-like dealkylation in the presence of $\mathrm{I}^{-}$counter anion to give the phosphonate complex 9a.
Table 4 Selected bond distances $(\AA)$ and angles $\left({ }^{\circ}\right)$ of $\left[\mathrm{RuCp}\left(\mathrm{PPh}_{3}\right)\right.$ $\left.\left\{\mathrm{P}(\mathrm{OMe})_{3}\right\}\left(\mathrm{COCH}_{2} \mathrm{Ph}\right)\right] 10$

\begin{tabular}{llll}
\hline $\mathrm{Ru}-\mathrm{P} 1$ & $2.2153(15)$ & $\mathrm{Ru}-\mathrm{P} 2$ & $2.3097(15)$ \\
$\mathrm{Ru}-\mathrm{C} 1$ & $2.010(5)$ & $\mathrm{C} 1-\mathrm{C} 2$ & $1.518(7)$ \\
$\mathrm{C} 1-\mathrm{O} 1$ & $1.326(7)$ & $\mathrm{C} 2-\mathrm{C} 3$ & $1.510(8)$ \\
& & & \\
$\mathrm{P} 1-\mathrm{Ru}-\mathrm{P} 2$ & $93.53(5)$ & $\mathrm{P} 1-\mathrm{Ru}-\mathrm{C} 1$ & $93.53(15)$ \\
$\mathrm{P} 2-\mathrm{Ru}-\mathrm{C} 1$ & $93.06(15)$ & $\mathrm{Ru}-\mathrm{C} 1-\mathrm{C} 2$ & $120.6(4)$ \\
$\mathrm{Ru}-\mathrm{C} 1-\mathrm{O} 1$ & $128.3(4)$ & $\mathrm{O} 1-\mathrm{C} 1-\mathrm{C} 2$ & $111.0(4)$ \\
$\mathrm{C} 1-\mathrm{C} 2-\mathrm{C} 3$ & $119.0(5)$ & & \\
\hline
\end{tabular}

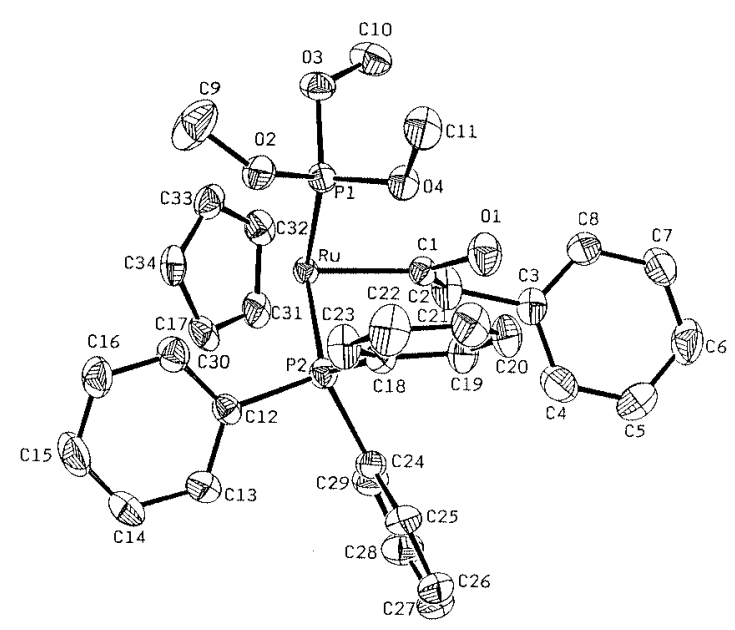

Fig. 4 An ORTEP drawing of complex 10.

In the presence of acid the newly formed carbon-carbon bond of complex $8 \mathbf{a}$ is easily cleaved. Since $\mathrm{NH}_{4} \mathrm{PF}_{6}$ was used in the preparation, it was converted into $\mathrm{HPF}_{6}$. Thus complex $8 \mathbf{a}$ with $\mathrm{PF}_{6}{ }^{-}$counter anion prepared at room temperature is unstable particularly in $\mathrm{CH}_{2} \mathrm{Cl}_{2}$ solution. It decomposes to give the acyl complex $\left[\mathrm{RuCp}\left(\mathrm{PPh}_{3}\right)\left\{\mathrm{P}(\mathrm{OMe})_{3}\right\}\left(\mathrm{COCH}_{2} \mathrm{Ph}\right)\right] \mathbf{1 0}$. With $\mathrm{I}^{-}$anion, $8 \mathbf{a}$ is stable for one day and then the Arbuzovlike dealkylation occurs to give neutral vinylidene complex 9a. The presence of $\mathrm{HPF}_{6}$ is required for the formation of acyl complex 10. In fact, in 1980, Bruce and Swincer ${ }^{20}$ reported a similar reaction and proposed a possible mechanism.

The molecular structure of complex $\mathbf{1 0}$ has been determined by an X-ray diffraction study. An ORTEP drawing is shown in Fig. 4. Selected bond distances and bond angles are listed in Table 4. The bond distance of $\mathrm{Ru}-\mathrm{Cl}(2.010(5) \AA)$ is typical for a $\mathrm{Ru}-\mathrm{C}$ single bond and that of $\mathrm{C} 1-\mathrm{O} 1$ (1.326(7) $\AA$ ) is typical for a $\mathrm{C}-\mathrm{O}$ double bond. The bond angles of $\mathrm{Ru}-\mathrm{C} 1-\mathrm{O} 1$ $\left(128.3(4)^{\circ}\right)$ and $\mathrm{O} 1-\mathrm{C} 1-\mathrm{C} 2\left(111.0(4)^{\circ}\right)$ are slightly deviated from that of a typical $\mathrm{C}\left(\mathrm{sp}^{2}\right)$ hybidization which may be due to the steric effect between the phenyl group of the acyl ligand and the bulky $\mathrm{PPh}_{3}$ ligand.

Our attempts to prepare similar vinylidene complexes with a trimethyl phosphite ligand all led to the corresponding neutral phosphonate complexes $\left[\mathrm{RuCp}\left(\mathrm{PPh}_{3}\right)\left\{\mathrm{P}(=\mathrm{O})(\mathrm{OMe})_{2}\right\}\{=\mathrm{C}=\right.$ $\left.\left.\mathrm{C}(\mathrm{Ph}) \mathrm{CH}_{2} \mathrm{R}\right\}\right], \mathrm{R}=\mathrm{C}_{6} \mathrm{~F}_{5} 9 \mathbf{b} ; \mathrm{R}=\mathrm{C}_{6} \mathrm{H}_{5} 9 \mathbf{9} ; p-\mathrm{NCC}_{6} \mathrm{H}_{4} 9 \mathbf{9} ; \mathrm{R}=$ $p-\mathrm{F}_{3} \mathrm{CC}_{6} \mathrm{H}_{4} 9 \mathrm{e} ; 1-\mathrm{C}_{10} \mathrm{H}_{7}$ 9f or $\mathrm{CO}_{2} \mathrm{CH}_{3} 9 \mathrm{~g}$ in high yield (Scheme 2 ). The most characteristic spectroscopic data of these vinylidene complexes again consist of a strongly deshielded resonance as a triplet at $\delta 348 \pm 3$ in the ${ }^{13} \mathrm{C}$ NMR spectrum and two doublet ${ }^{31} \mathrm{P}$ NMR resonances at around $\delta 96 \pm 2$ and $49 \pm 2$ attributed to $\mathrm{P}(\mathrm{O})(\mathrm{OMe})_{2}$ and $\mathrm{PPh}_{3}$, respectively. Complexes 9a-9g are all deep red oils, possibly because of the presence of phosphonate ligand and are stable in solution and in air for more than one month. Attempted deprotonation failed to give a cyclopropenyl complex, possibly due to lack of a positive charge.

\section{Conclusion}

The $[2+2]$ cycloaddition of the unsymmetrical olefin $\mathrm{HPhC}=$ 
$\mathrm{C}(\mathrm{CN})_{2}$ to $\left[\mathrm{RuCp}(\mathrm{L})\left(\mathrm{L}^{\prime}\right)(\mathrm{C} \equiv \mathrm{CPh})\right]$ gave cyclobutenyl complexes 2a-2c and butadienyl complexes 3a-3c. Further pyrolysis of 2a and 3a gave the $\eta^{3}$-allylic complex $\mathbf{4}$ by loss of a $\mathrm{PPh}_{3}$ ligand. The reaction of 1 a with $\mathrm{ClPhC}=\mathrm{C}(\mathrm{CN})_{2}$ proceeded through an Arbuzov-like dealkylation and resulted in formation of the neutral vinylidene complex $\left[\mathrm{RuCp}\left(\mathrm{PPh}_{3}\right)\right.$ $\left.\left\{\mathrm{P}(\mathrm{O})(\mathrm{OMe})_{2}\right\}\left\{=\mathrm{C}=\mathrm{C}(\mathrm{Ph}) \mathrm{C}(\mathrm{Ph}) \mathrm{C}(\mathrm{CN})_{2}\right\}\right] \mathbf{6}$. The reaction of $\mathbf{1 b}$ and 1c with $\mathrm{Cl}(\mathrm{Ph}) \mathrm{C}=\mathrm{C}(\mathrm{CN})_{2}$ afforded cationic vinylidene complexes $\left[\mathrm{RuCp}(\mathrm{L})\left(\mathrm{L}^{\prime}\right)\left\{=\mathrm{C}=\mathrm{C}(\mathrm{Ph}) \mathrm{C}(\mathrm{Ph}) \mathrm{C}(\mathrm{CN})_{2}\right\} \mathrm{Cl}\right.$ 7. In $\mathrm{Cl}(\mathrm{Ph}) \mathrm{C}=\mathrm{C}(\mathrm{CN})_{2}$, the two strong electron-withdrawing $\mathrm{CN}$ groups make the chlorine atom a good leaving group. The Arbuzov-like dealkylation reaction is not uncommon for such a ruthenium entity with a vinylidene ligand. The reaction of 1a with organic halide $\mathrm{XCH}_{2} \mathrm{R}$ afforded neutral phosphonate vinylidene complexes $\left[\mathrm{RuCp}\left(\mathrm{PPh}_{3}\right)\left\{\mathrm{P}(\mathrm{O})(\mathrm{OMe})_{2}\right\}\{=\mathrm{C}=\mathrm{C}(\mathrm{Ph})\right.$ $\left.\mathrm{CH}_{2} \mathrm{R}\right\}$ ].

\section{Experimental}

\section{General procedures}

All manipulations were performed under nitrogen using vacuum-line, dry-box, and standard Schlenk techniques. Dichloromethane was distilled from $\mathrm{CaH}_{2}$ and diethyl ether and THF from sodium diphenylketyl. All other solvents and reagents were of reagent grade used without further purification. The NMR spectra were recorded on Bruker AC-200 and AM-300WB FT-NMR spectrometers at room temperature (unless stated otherwise) and are reported in units of $\delta$ with residual protons in the solvents as an initial standard $\left(\mathrm{CDCl}_{3}, \delta\right.$ 7.24: acetone- $\left.d_{6}, \delta 2.04\right)$. The FAB mass spectra were recorded on a JEOL SX-102A spectrometer. The complexes $\left[\mathrm{RuCp}(\mathrm{L})\left(\mathrm{L}^{\prime}\right)(\mathrm{C} \equiv \mathrm{CPh})\right] \mathbf{1 a}\left[\mathrm{L}=\mathrm{PPh}_{3}, \mathrm{~L}^{\prime}=\mathrm{P}(\mathrm{OMe})_{3}\right]$, $\mathbf{1 b}$ $\left(\mathrm{LL}^{\prime}=\mathrm{dppe}\right)$ and 1c $\left(\mathrm{L}=\mathrm{PPh}_{3}, \mathrm{~L}=\mathrm{CN}^{t} \mathrm{Bu}\right)$ were prepared following the methods reported. ${ }^{21}$ Elemental analyses and $\mathrm{X}$-ray diffraction studies were carried out at the Regional Center of Analytical Instrument located at the National Taiwan University.

\section{Syntheses}

$\left[\mathrm{RuCp}\left(\mathrm{PPh}_{3}\right)\left\{\mathrm{P}(\mathrm{OMe})_{3}\right\}\left\{\mathrm{C}=\mathrm{C}(\mathrm{Ph}) \mathrm{CH}(\mathrm{Ph}) \mathrm{C}(\mathrm{CN})_{2}\right\}\right]$ 2a and $\left[\mathrm{RuCp}\left(\mathrm{PPh}_{3}\right)\left\{\mathbf{P}(\mathrm{OMe})_{3}\right\}\left\{\mathbf{C}\left[=\mathbf{C}(\mathbf{C N})_{2}\right] \mathbf{C}(\mathbf{P h}) \mathbf{C H}(\mathbf{P h})\right\}\right]$ 3a. To a solution of complex $\mathbf{1 a}(500 \mathrm{mg}, 0.766 \mathrm{mmol})$ in $\mathrm{CH}_{2} \mathrm{Cl}_{2}(20 \mathrm{~mL})$ was added $\mathrm{H}(\mathrm{Ph}) \mathrm{C}=\mathrm{C}(\mathrm{CN})_{2}(354.3 \mathrm{mg}, 2.29 \mathrm{mmol})$ and the solution stirred for $1 \mathrm{~h}$ at room temperature. The ${ }^{1} \mathrm{H}$ and ${ }^{31} \mathrm{P}$ NMR spectra of the product indicated formation of two major products 2a and 3a in a ratio of $1: 1$. Reduced the solvent to $c a$. $3 \mathrm{~mL}$ under vacuum followed by addition of hexane gave yellow precipitates. After filtration, the solid was further washed with $2 \times 20 \mathrm{~mL}$ of hexane and $10 \mathrm{~mL}$ of diethyl ether and dried under vacuum to give a mixture of $\mathbf{2 a}$ and $\mathbf{3 a}$ ( $544.5 \mathrm{mg}, 0.674$ $\mathrm{mmol}$ ) in a total yield of $75 \%$. Crystallization of the mixture from $\mathrm{CH}_{2} \mathrm{Cl}_{2}$-hexane $(1: 3)$ gave yellow crystals. At room temperature $3 \mathbf{a}$ in $\mathrm{CDCl}_{3}$ solution was converted into a mixture of 2a and 3a (1:1) in $30 \mathrm{~min}$. Spectroscopic data for 2a: ${ }^{1} \mathrm{H}$ NMR $\left(\mathrm{CDCl}_{3}\right): \delta 7.90-6.35(\mathrm{~m}, 25 \mathrm{H}, \mathrm{Ph}), 5.10(\mathrm{~s}, 1 \mathrm{H}, \mathrm{CH}), 5.01(\mathrm{~s}$, $\mathrm{Cp})$ and $3.27\left(\mathrm{~d}, 9 \mathrm{H}, J_{\mathrm{H}-\mathrm{P}}=10.93 \mathrm{~Hz}, \mathrm{OCH}_{3}\right) ;{ }^{31} \mathrm{P} \mathrm{NMR}$ $\left(\mathrm{CDCl}_{3}\right) \delta 148.9$ and $58.8\left(2 \mathrm{~d}, J_{\mathrm{P}-\mathrm{P}}=70.2 \mathrm{~Hz}\right) ;{ }^{13} \mathrm{C} \mathrm{NMR}$ $\left(\mathrm{CDCl}_{3}\right) \delta 164.6\left(\mathrm{q}, \mathrm{C}_{\alpha}, J_{\mathrm{C}-\mathrm{P}}=12.6,7.2\right), 163.0(\mathrm{CPh}), 137.4$ $123.0(\mathrm{Ph}), 113.7,112.5(2 \mathrm{CN}), 82.9\left(\mathrm{C}(\mathrm{CN})_{2}\right), 82.6(\mathrm{Cp})$ and $52.2\left(\mathrm{~d}, J_{\mathrm{C}-\mathrm{P}}=9.0 \mathrm{~Hz}, \mathrm{OCH}_{3}\right) ; \mathrm{MS}\left(\mathrm{m} / \mathrm{z},{ }^{102} \mathrm{Ru}\right) 809.1\left(\mathrm{M}^{+}+1\right)$, 654.1 $\left(\mathrm{M}^{+}-\mathrm{PhHC}=\mathrm{C}(\mathrm{CN})_{2}\right)$ and $429.0\left(\mathrm{M}^{+}-\mathrm{PhHC}=\mathrm{C}(\mathrm{CN})_{2-}\right.$ $\mathrm{CCPh})$. Spectroscopic data for 3a: ${ }^{1} \mathrm{H}$ NMR $\left(\mathrm{CDCl}_{3}\right) \delta 7.76$ $6.44(\mathrm{~m}, 25 \mathrm{H}, \mathrm{Ph}), 4.66(\mathrm{~s}, 1 \mathrm{H}, \mathrm{CH}), 4.74(\mathrm{~s}, \mathrm{Cp})$ and 3.37 $\left(\mathrm{d}, 9 \mathrm{H}, J_{\mathrm{H}-\mathrm{P}}=11.13 \mathrm{~Hz}, \mathrm{OCH}_{3}\right) ;{ }^{31} \mathrm{P} \mathrm{NMR}\left(\mathrm{CDCl}_{3}\right) \delta 148.2$ and $58.3\left(2 \mathrm{~d}, \quad J_{\mathrm{P}-\mathrm{P}}=70.35 \mathrm{~Hz}\right) ;{ }^{13} \mathrm{C}$ NMR $\left(\mathrm{CDCl}_{3}\right) \delta 165.8(\mathrm{q}$, $\left.\mathrm{C}_{\alpha}, J_{\mathrm{C}-\mathrm{P}}=15.7,8.9\right), 162.9(\mathrm{CPh}), 139.6-118.2(\mathrm{Ph}), 117.1$, $116.6(2 \mathrm{CN}), 84.2\left(\mathrm{C}(\mathrm{CN})_{2}\right), 82.7(\mathrm{Cp}), 60.5(\mathrm{CHPh})$ and $52.1\left(\mathrm{~d}, J_{\mathrm{C}-\mathrm{P}}=9.0 \mathrm{~Hz}, \mathrm{OCH}_{3}\right) ; \mathrm{MS}\left(\mathrm{m} / \mathrm{z},{ }^{102} \mathrm{Ru}\right) 809.1\left(\mathrm{M}^{+}+\right.$ 1), $654.1\left(\mathrm{M}^{+}-\mathrm{PhHC}=\mathrm{C}(\mathrm{CN})_{2}\right)$ and $429.0\left(\mathrm{M}^{+}-\mathrm{PhHC}=\right.$
$\left.\mathrm{C}(\mathrm{CN})_{2}-\mathrm{CCPh}\right)$. Calc. for $\mathrm{C}_{44} \mathrm{H}_{40} \mathrm{~N}_{2} \mathrm{O}_{3} \mathrm{P}_{2} \mathrm{Ru}: \mathrm{C}, 65.42 ; \mathrm{H}, 4.99$; $\mathrm{N}, 3.47$. Found: C: $65.73 ; \mathrm{H}, 4.85 ; \mathrm{N}, 3.59 \%$.

[RuCp $\left.\left(\mathbf{P P h}_{3}\right)\left(\mathrm{CN}^{t} \mathrm{Bu}\right)\left\{\mathrm{C}=\mathbf{C}(\mathbf{P h}) \mathbf{C H}(\mathbf{P h}) \mathbf{C}(\mathbf{C N})_{2}\right\}\right]$ 2c. To a solution of complex $1 \mathrm{c}(500 \mathrm{mg}, 0.817 \mathrm{mmol})$ in $\mathrm{CH}_{2} \mathrm{Cl}_{2}(20 \mathrm{~mL})$ was added $\mathrm{H}(\mathrm{Ph}) \mathrm{C}=\mathrm{C}(\mathrm{CN})_{2}(377.5 \mathrm{mg}, 2.45 \mathrm{mmol})$ and the solution was stirred for $10 \mathrm{~min}$ at room temperature. Removal of the solvent under vacuum followed by addition of hexane gave a yellow precipitate. After filtration, the solid was further washed with $2 \times 20 \mathrm{~mL}$ of hexane and $10 \mathrm{~mL}$ of diethyl ether and dried under vacuum to give the product $2 \mathrm{c}(544.5 \mathrm{mg}$, yield $87 \%)$. Spectroscopic data for $2 \mathrm{c}:{ }^{1} \mathrm{H}$ NMR $\left(\mathrm{C}_{6} \mathrm{D}_{6}\right) \delta 7.89-6.90$ (m, $25 \mathrm{H}, \mathrm{Ph}), 4.98$ (s, Cp), $4.85(\mathrm{~s}, 1 \mathrm{H}, \mathrm{CH})$ and $1.21(\mathrm{~s}, 9 \mathrm{H}$, $\left.\mathrm{C}\left(\mathrm{CH}_{3}\right)_{3}\right) ;{ }^{31} \mathrm{P}$ NMR $\left(\mathrm{CDCl}_{3}\right) \delta 59.2 ;{ }^{13} \mathrm{C} \mathrm{NMR}\left(\mathrm{CDCl}_{3}\right) \delta 243.3$ $\left(\mathrm{d}, \mathrm{CN}^{t} \mathrm{Bu}, J_{\mathrm{C}-\mathrm{P}}=10.1\right), 167.2\left(\mathrm{~d}, \mathrm{C}_{\alpha}, J_{\mathrm{C}-\mathrm{P}}=9.9 \mathrm{~Hz}\right), 158.7$ (CPh), 137.8-125.0 (Ph), 117.6, 115.5 (2CN), $84.0(\mathrm{Cp}), 82.4$

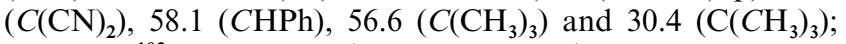
MS $\left(\mathrm{m} / z,{ }^{102} \mathrm{Ru}\right) 767.2\left(\mathrm{M}^{+}+1\right), 613.0\left(\mathrm{M}^{+}-\mathrm{PhHC}=\mathrm{C}(\mathrm{CN})_{2}\right)$ and $512.0\left(\mathrm{M}^{+}-\mathrm{PhHC}=\mathrm{C}(\mathrm{CN})_{2}-\mathrm{CCPh}\right)$.

$\left[\mathrm{RuCp}\left(\mathrm{PPh}_{3}\right)\left(\mathrm{CN}^{t} \mathrm{Bu}\right)\left\{\mathrm{C}\left[=\mathrm{C}(\mathrm{CN})_{2}\right] \mathrm{C}(\mathrm{Ph}) \mathrm{CH}(\mathrm{Ph})\right\}\right] \quad 3 \mathrm{c} . \quad \mathrm{A}$ $\mathrm{CH}_{2} \mathrm{Cl}_{2}$ solution of complex $2 \mathrm{c}(200 \mathrm{mg}, 0.261 \mathrm{mmol})$ was stirred at room temperature for $2 \mathrm{~h}$. Removal of the solvent under vacuum followed by addition of hexane gave a yellow precipitate which was dried under vacuum, giving the product 3c $(186.0 \mathrm{mg}, 93 \%) .{ }^{1} \mathrm{H}$ NMR $\left(\mathrm{CDCl}_{3}\right): \delta 7.89-6.72(\mathrm{~m}, 25 \mathrm{H}$, $\mathrm{Ph}), 5.33(\mathrm{~s}, \mathrm{H}), 4.40(\mathrm{~s}, \mathrm{Cp})$ and $1.05\left(\mathrm{~s}, 9 \mathrm{H}, \mathrm{C}\left(\mathrm{CH}_{3}\right)_{3}\right) .{ }^{31} \mathrm{P}$ $\mathrm{NMR}\left(\mathrm{CDCl}_{3}\right): \delta$ 56.0. ${ }^{13} \mathrm{C}$ NMR $\left(\mathrm{CDCl}_{3}\right): \delta 233.8$ (d, $\left.J_{\mathrm{C}-\mathrm{P}}=10.1, C \mathrm{~N}^{t} \mathrm{Bu}\right), 158.3\left(\mathrm{~d}, \mathrm{C}_{\alpha}, J_{\mathrm{C}-\mathrm{P}}=9.9 \mathrm{~Hz}\right), 155.1(C \mathrm{Ph})$, 137.4-115.5 ( Ph), 113.6, $112.5(2 \mathrm{CN}), 88.9\left(\mathrm{C}(\mathrm{CN})_{2}\right), 84.2(\mathrm{Cp})$,

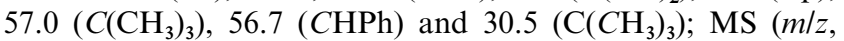
$\left.{ }^{102} \mathrm{Ru}\right): 767.2\left(\mathrm{M}^{+}+1\right), 505.0\left(\mathrm{M}^{+}+1-\mathrm{PPh}_{3}\right)$ and 422.0 $\left(\mathrm{M}^{+}+1-\mathrm{PPh}_{3}{ }^{-} \mathrm{BuNC}\right)$. Calc. for $\mathrm{C}_{40} \mathrm{H}_{46} \mathrm{~N}_{3} \mathrm{PRu}$ : C, 72.04; $\mathrm{H}$, 5.26; N, 5.48. Found: C, 72.66; H, 5.07; N, 5.33\%.

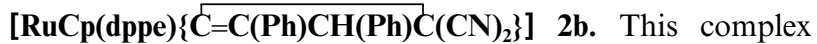
$(523.3 \mathrm{mg}, 0.638 \mathrm{mmol}$, yield $85 \%)$ was prepared from $\mathbf{1 b}(500$ $\mathrm{mg}, 0.751 \mathrm{mmol}$ ) using the same procedure as that for $\mathbf{2 c}$ and a reaction time of $1 \mathrm{~h}$ at room temperature. ${ }^{1} \mathrm{H}$ NMR $\left(\mathrm{C}_{6} \mathrm{D}_{6}\right)$ : $\delta$ 8.17-6.63 (m, 30 H, Ph), $5.24(\mathrm{~s}, 1 \mathrm{H}, \mathrm{CH}), 4.67(\mathrm{~s}, \mathrm{Cp})$ and 2.68-2.40 (m, $\left.\mathrm{CH}_{2} \mathrm{CH}_{2}\right) \cdot{ }^{31} \mathrm{P} \mathrm{NMR}\left(\mathrm{CDCl}_{3}\right): \delta 98.1$ and 96.9 (2br). ${ }^{13} \mathrm{C}$ NMR $\left(\mathrm{CDCl}_{3}\right): \delta 164.9$ (t, $\left.\mathrm{C}_{a}, J_{\mathrm{C}-\mathrm{P}}=17.0\right), 157.1$ $(C \mathrm{Ph}), 136.8-122.8(\mathrm{Ph}), 119.1,117.4(2 \mathrm{CN}), 84.9(\mathrm{Cp}), 82.3$ $\left(C(\mathrm{CN})_{2}\right), 30.1$ and $29.5\left(2 \mathrm{~d}, J_{\mathrm{C}-\mathrm{P}}=18.0 \mathrm{~Hz}\right) ; \mathrm{MS}\left(\mathrm{m} / \mathrm{z},{ }^{102} \mathrm{Ru}\right)$ $821.1\left(\mathrm{M}^{+}+1\right), 666.0\left(\mathrm{M}^{+}-\mathrm{PhHC}=\mathrm{C}(\mathrm{CN})_{2}\right)$ and $565.0\left(\mathrm{M}^{+}-\right.$ $\left.\mathrm{PhHC}=\mathrm{C}(\mathrm{CN})_{2}-\mathrm{CCPh}\right)$. Complex $\left[\mathrm{RuCp}(\mathrm{dppe})\left\{\mathrm{C}\left[=\mathrm{C}(\mathrm{CN})_{2}\right]-\right.\right.$ $\mathrm{C}(\mathrm{Ph}) \mathrm{CH}(\mathrm{Ph})\}]$ 3b $(180.0 \mathrm{mg}$, yield $90 \%)$ was prepared from $\mathbf{2 b}$ $(200 \mathrm{mg}, 0.244 \mathrm{mmol})$ using the same procedure as that for $\mathbf{3 c}$ and the reaction time was $8 \mathrm{~h}$ at room temperature. ${ }^{1} \mathrm{H}$ NMR $\left(\mathrm{C}_{6} \mathrm{D}_{6}\right): \delta 7.91-6.97(\mathrm{~m}, 30 \mathrm{H}, \mathrm{Ph}), 5.95(\mathrm{br}, 1 \mathrm{H}, \mathrm{CH}), 4.43(\mathrm{~s}$, $\mathrm{Cp})$ and $2.70-2.05\left(\mathrm{~m}, \mathrm{CH}_{2} \mathrm{CH}_{2}\right) .{ }^{31} \mathrm{P} \mathrm{NMR}\left(\mathrm{CDCl}_{3}\right): \delta 94.0$ and 92.3 (2br). ${ }^{13} \mathrm{C} \mathrm{NMR}\left(\mathrm{CDCl}_{3}\right): \delta 164.9\left(\mathrm{t}, \mathrm{C}_{\alpha}, J_{\mathrm{C}-\mathrm{P}}=17.0\right), 157.1$ $(C \mathrm{Ph}), 136.8-122.8(\mathrm{Ph}), 119.1,117.4(2 \mathrm{CN}), 84.9(\mathrm{Cp}), 82.3$ $(C(\mathrm{CN}) 2), 30.1$ and $29.5\left(2 \mathrm{~d}, J_{\mathrm{C}-\mathrm{P}}=18.0 \mathrm{~Hz}\right)$; $\mathrm{MS}\left(\mathrm{m} / \mathrm{z},{ }^{102} \mathrm{Ru}\right)$ $821.1\left(\mathrm{M}^{+}+1\right)$ and $565.0\left(\mathrm{M}^{+}-\mathrm{PhHC}=\mathrm{C}(\mathrm{CN})_{2}-\mathrm{CCPh}\right)$. Calc. for $\mathrm{C}_{49} \mathrm{H}_{40} \mathrm{~N}_{2} \mathrm{P}_{2} \mathrm{Ru}$ : C, 71.78; H, 4.92; N, 3.42. Found: C, 72.05; $\mathrm{H}, 4.75 ; \mathrm{N}, 3.32 \%$.

$\left[\mathrm{RuCp}\left\{\mathbf{P}(\mathrm{OMe})_{3}\right\}\left\{\boldsymbol{\eta}^{3}-\mathrm{C}\left[=\mathbf{C}(\mathbf{C N})_{2}\right] \mathbf{C}(\mathbf{P h}) \mathbf{C H}(\mathbf{P h})\right\}\right]$ 4. To a solution of complex 1a $(500 \mathrm{mg}, 0.766 \mathrm{mmol})$ in benzene $\mathrm{H}(\mathrm{Ph}) \mathrm{C}=\mathrm{C}(\mathrm{CN})_{2}(345.3 \mathrm{mg}, 2.29 \mathrm{mmol})$ was added and the solution refluxed for $48 \mathrm{~h}$. Removal of benzene solution under vacuum followed by addition of $50 \mathrm{~mL}$ of hexane gave a yellow precipitate. After filtration, the solid was further washed with $20 \times 2 \mathrm{~mL}$ of hexane, $10 \mathrm{~mL}$ of diethyl ether and dried under vacuum, giving the product $4(368 \mathrm{mg})$ in $88 \%$ yield. ${ }^{1} \mathrm{H}$ NMR $\left(\mathrm{CDCl}_{3}\right): \delta 7.45-6.72(\mathrm{~m}, 10 \mathrm{H}, \mathrm{Ph}), 4.94(\mathrm{~s}, \mathrm{Cp}), 3.63(\mathrm{~d}, 9 \mathrm{H}$, $\left.J_{\mathrm{H}-\mathrm{P}}=11.75, \mathrm{OCH}_{3}\right)$ and $3.43\left(\mathrm{~d}, 1 \mathrm{H}, \mathrm{CH}(\mathrm{Ph}), J_{\mathrm{H}-\mathrm{P}}=12.30\right.$ $\mathrm{Hz}) .{ }^{31} \mathrm{P} \mathrm{NMR}\left(\mathrm{CDCl}_{3}\right): \delta 159.35\left(\mathrm{P}(\mathrm{OMe})_{3}\right) \cdot{ }^{13} \mathrm{C} \mathrm{NMR}\left(\mathrm{CDCl}_{3}\right)$ : 
$\delta 223.5\left(\mathrm{~d}, J_{\mathrm{C}-\mathrm{P}}=14.6, \mathrm{C}_{\alpha}\right), 141.6,137.0,131.0-126.0(\mathrm{Ph})$, $118.2,113.0(2 \mathrm{CN}), 86.1(\mathrm{Cp}), 78.6\left(\mathrm{~d}, J_{\mathrm{C}-\mathrm{P}}=8.68, C(\mathrm{CN})_{2}\right)$, $71.3(C(\mathrm{Ph})=\mathrm{CH}(\mathrm{Ph}))$ and $52.6\left(\mathrm{~d}, J_{\mathrm{C}-\mathrm{P}}=7.67 \mathrm{~Hz}, \mathrm{OCH}_{3}\right)$; MS $\left(\mathrm{m} / \mathrm{z},{ }^{102} \mathrm{Ru}\right): 546.1\left(\mathrm{M}^{+}\right)$and $291.0\left(\mathrm{M}^{+}-\mathrm{PhHC}=\mathrm{C}(\mathrm{CN})_{2}\right.$ $\mathrm{CCPh}$ ). Calc. for $\mathrm{C}_{26} \mathrm{H}_{25} \mathrm{~N}_{2} \mathrm{O}_{3} \mathrm{PRu}: \mathrm{C}, 57.24 ; \mathrm{H}, 4.62 ; \mathrm{N}, 5.14$. Found: C, 57.65; H, 4.48; N, 5.03\%.

$\left[\mathrm{RuCp}\left\{\mathrm{P}(\mathrm{OMe})_{3}\right\}\left(\mathrm{CN}^{t} \mathrm{Bu}\right)\left\{\mathrm{C}\left[\mathrm{C}(\mathrm{CN})_{2}\right] \mathrm{C}(\mathrm{Ph}) \mathrm{CH}(\mathrm{Ph})\right\}\right]$ 5. To a solution of complex 4 (100 mg, $0.183 \mathrm{mmol})$ in $\mathrm{CH}_{2} \mathrm{Cl}_{2},{ }^{t} \mathrm{BuCN}$ $(62.1 \mu \mathrm{L}, 0.550 \mathrm{mmol})$ was added and the solution refluxed for $48 \mathrm{~h}$. Removal of the solvent under vacuum followed by addition of $30 \mathrm{~mL}$ of hexane gave a yellow precipitate. After filtration, the solid was further washed with $10 \times 2 \mathrm{~mL}$ of hexane, $10 \mathrm{~mL}$ of diethyl ether and dried under vacuum, giving the product $5(82.7 \mathrm{mg}$, yield $72 \%)$. ${ }^{1} \mathrm{H}$ NMR $\left(\mathrm{CDCl}_{3}\right): \delta 7.65$ $6.96(\mathrm{~m}, 25 \mathrm{H}, \mathrm{Ph}), 5.97$ (s, 1 H, CH), 4.63 (s, Cp), 3.57 (d, $9 \mathrm{H}$, $\left.J_{\mathrm{H}-\mathrm{P}}=11.55 \mathrm{~Hz}, \mathrm{OCH}_{3}\right)$ and $1.34\left(\mathrm{~s}, \mathrm{C}\left(\mathrm{CH}_{3}\right)_{3}\right) .{ }^{31} \mathrm{P} \mathrm{NMR}$ $\left(\mathrm{CDCl}_{3}\right): \delta$ 159.2. ${ }^{13} \mathrm{C}$ NMR $\left(\mathrm{CDCl}_{3}\right): \delta 236.0\left(\mathrm{~d}, \mathrm{CN}^{t} \mathrm{Bu}\right.$, $\left.J_{\mathrm{C}-\mathrm{P}}=17.9\right), 154.5,138.7-117.8\left(\mathrm{Ph}, \mathrm{C}_{\beta}\right.$ and $\left.\mathrm{C}_{\gamma}\right), 119.6,115.3$ $(2 \mathrm{CN}), 85.2(\mathrm{Cp}), 57.0\left(\mathrm{~s}, \mathrm{C}\left(\mathrm{CH}_{3}\right)_{3}\right), 51.8\left(\mathrm{~d}, J_{\mathrm{C}-\mathrm{P}}=3.8 \mathrm{~Hz}\right.$, $\left.\mathrm{OCH}_{3}\right)$ and $29.6\left(\mathrm{~s}, \mathrm{C}\left(\mathrm{CH}_{3}\right)_{3}\right)$; $\mathrm{MS}\left(\mathrm{m} / \mathrm{z},{ }^{102} \mathrm{Ru}\right): 629.1\left(\mathrm{M}^{+}\right)$, $505.1\left(\mathrm{M}^{+}-\mathrm{P}(\mathrm{OMe})_{3}\right)$ and $422.0\left(\mathrm{M}^{+}-\mathrm{P}(\mathrm{OMe})_{3}{ }^{t} \mathrm{BuNC}\right)$ Calc. for $\mathrm{C}_{31} \mathrm{H}_{34} \mathrm{~N}_{3} \mathrm{O}_{3} \mathrm{PRu}$ : C, 59.22; H, 5.45; N, 6.68. Found: C, 59.76; H, 5.32; N, 6.47\%.

$\left[\mathrm{RuCp}\left(\mathrm{PPh}_{3}\right)\left\{\mathrm{P}(\mathrm{O})(\mathrm{OMe})_{2}\right\}\left\{=\mathrm{C}=\mathrm{C}(\mathrm{Ph}) \mathrm{C}(\mathrm{Ph}) \mathrm{C}(\mathrm{CN})_{2}\right\}\right] \quad 6$. To a solution of complex $1 \mathrm{a}(150 \mathrm{mg}, 0.230 \mathrm{mmol})$ in $\mathrm{CH}_{2} \mathrm{Cl}_{2}$, $\mathrm{Cl}(\mathrm{Ph}) \mathrm{C}=\mathrm{C}(\mathrm{CN})_{2} \quad(24.9 \mathrm{mg}, 0.689 \mathrm{mmol})$ was added and the solution stirred at room temperature for $24 \mathrm{~h}$, the solution changing from yellow to red. At this stage, crystals of $\mathbf{6}$ containing $(\mathrm{OH}) \mathrm{PhC}=\mathrm{C}(\mathrm{CN})_{2}$ formed if the solvent slowly evaporated in the air. The solvent was reduced to $c a .5 \mathrm{~mL}$ then the mixture was added to a $50 \mathrm{~mL}$ solution of diethyl ether yielding orange-red precipitates of 6 . In order to remove $(\mathrm{OH}) \mathrm{PhC}=\mathrm{C}(\mathrm{CN})_{2}$ (which could be formed by the reaction of water in the solution and excess of $\left.\mathrm{Cl}(\mathrm{Ph}) \mathrm{C}=\mathrm{C}(\mathrm{CN})_{2}\right)$, the precipitate was further washed with $10 \mathrm{~mL}$ of diethyl ether and subsequently with $10 \times 2 \mathrm{~mL}$ of hexane, then dried under vacuum giving $6(160.0 \mathrm{mg}$, yield $87.9 \%)$. ${ }^{1} \mathrm{H} \mathrm{NMR}\left(\mathrm{CDCl}_{3}\right)$ : $\delta 7.80-7.14(\mathrm{~m}, 25 \mathrm{H}, \mathrm{Ph}), 5.33(\mathrm{~s}, \mathrm{Cp}), 3.20(\mathrm{~d}, 3 \mathrm{H}$, $\left.J_{\mathrm{H}-\mathrm{P}}=11.61, \mathrm{OCH}_{3}\right) 2.96\left(\mathrm{~d}, 3 \mathrm{H}, J_{\mathrm{H}-\mathrm{P}}=11.63 \mathrm{~Hz}, \mathrm{OCH}_{3}\right) .{ }^{31} \mathrm{P}$ $\operatorname{NMR}\left(\mathrm{CDCl}_{3}\right): \delta 105.6$ and $43.7\left(2 \mathrm{~d}, J_{\mathrm{P}-\mathrm{P}}=47.8 \mathrm{~Hz}\right) \cdot{ }^{13} \mathrm{C}$ NMR $\left(\mathrm{CDCl}_{3}\right): \delta 339.8\left(\mathrm{q},{ }^{1} J_{\mathrm{C}-\mathrm{P}}=14.1,{ }^{2} J_{\mathrm{C}-\mathrm{P}}=4.7, \mathrm{C}_{\alpha}\right), 167.6\left(\mathrm{C}_{\beta}\right)$, 134.4-127.8 (Ph), 114.8, $114.0(2 \mathrm{CN}), 94.2(\mathrm{Cp}), 85.6\left(\mathrm{C}_{\gamma}\right)$, $78.2\left(\mathrm{C}(\mathrm{CN})_{2}\right)$ and $52.3\left(\mathrm{t}, J_{\mathrm{C}-\mathrm{P}}=11.2 \mathrm{~Hz}, \mathrm{P}(\mathrm{O})\left(\mathrm{OCH}_{3}\right)_{2}\right)$; MS $\left(\mathrm{m} / \mathrm{z},{ }^{102} \mathrm{Ru}\right): 793.0\left(\mathrm{M}^{+}+1\right), 539.0\left(\mathrm{M}^{+}-\mathrm{CH}=\mathrm{C}(\mathrm{CN})_{2}\right)$ and $428.9\left(\mathrm{M}^{+}-\mathrm{CH}=\mathrm{C}(\mathrm{CN})_{2}-\mathrm{P}(\mathrm{O})(\mathrm{OMe})_{2}\right)$. Calc. for $\mathrm{C}_{43} \mathrm{H}_{36} \mathrm{~N}_{2-}$ $\mathrm{O}_{3} \mathrm{P}_{2} \mathrm{Ru}: \mathrm{C}, 65.22 ; \mathrm{H}, 4.58 ; \mathrm{N}, 3.54$. Found: $\mathrm{C}, 65.56 ; \mathrm{H}, 4.77 ; \mathrm{N}$, $3.34 \%$.

Complexes $\left[\mathrm{RuCp}(\mathrm{dppe})\left\{=\mathrm{C}=\mathrm{C}(\mathrm{Ph}) \mathrm{C}(\mathrm{Ph}) \mathrm{C}(\mathrm{CN})_{2}\right\}\right]\left[\mathrm{PF}_{6}\right]$ 7b $(83 \%$ yield $)$ and $\left[\mathrm{RuCp}\left(\mathrm{PPh}_{3}\right)\left({ }^{t} \mathrm{BuNC}\right)\{=\mathrm{C}=\mathrm{C}(\mathrm{Ph}) \mathrm{C}(\mathrm{Ph})\right.$ $\left.\left.\mathrm{C}(\mathrm{CN})_{2}\right\}\right]\left[\mathrm{PF}_{6}\right] 7 \mathrm{c}(76 \%$ yield) were prepared using the same procedure as that for 6 and $\mathrm{NH}_{4} \mathrm{PF}_{6}$ was added to exchange the counter anion after the reaction was complete. Spectroscopic data for 7c: ${ }^{1} \mathrm{H}$ NMR $\left(\mathrm{CDCl}_{3}\right) \delta 7.78-6.92(\mathrm{~m}, 25 \mathrm{H}, \mathrm{Ph}), 5.66$ (s, $\mathrm{Cp})$ and $1.17\left(\mathrm{~s}, 9 \mathrm{H}, \mathrm{C}\left(\mathrm{CH}_{3}\right)_{3}\right) ;{ }^{31} \mathrm{P} \mathrm{NMR}\left(\mathrm{CDCl}_{3}\right) \delta 44.07$; ${ }^{13} \mathrm{C}$ NMR $\left(\mathrm{CDCl}_{3}\right) \delta 345.2\left(\mathrm{~d}, J_{\mathrm{C}-\mathrm{P}}=12.0, \mathrm{C}_{\alpha}\right), 198.6(\mathrm{~d}$, $\left.J_{\mathrm{C}-\mathrm{P}}=16.3, C \mathrm{~N}^{t} \mathrm{Bu}\right), 164.7\left(\mathrm{C}_{\alpha}\right), 137.1-126.0(\mathrm{Ph}), 113.7,112.4$ $(2 \mathrm{CN}), 94.9(\mathrm{Cp}), 85.5\left(\mathrm{~d}, J_{\mathrm{C}-\mathrm{P}}=13.74 \mathrm{~Hz}, \mathrm{C}_{\gamma}\right), 78.3\left(C(\mathrm{CN})_{2}\right)$, $60.5\left(\mathrm{C}\left(\mathrm{CH}_{3}\right)_{3}\right)$ and $29.8\left(\mathrm{~s}, \mathrm{C}\left(\mathrm{CH}_{3}\right)_{3}\right) ; \mathrm{MS}\left(\mathrm{m} / \mathrm{z},{ }^{102} \mathrm{Ru}\right): 766.1$ $\left(\mathrm{M}^{+}-\mathrm{PF}_{6}\right), 540.0 \quad\left(\mathrm{M}^{+}-\mathrm{PF}_{6}-\mathrm{CH}=\mathrm{C}(\mathrm{CN})_{2}+\mathrm{CO}\right)$ and $512.0\left(\mathrm{M}^{+}-\mathrm{PF}_{6}-\mathrm{CH}=\mathrm{C}(\mathrm{CN})_{2}\right)$. Calc. for $\mathrm{C}_{49} \mathrm{H}_{39} \mathrm{~F}_{6} \mathrm{~N}_{2} \mathrm{P}_{3} \mathrm{Ru}: \mathrm{C}$, 61.06; H, 4.08; N, 2.91. Found: C, 61.37; H, 3.96; N, 2.78\%. Spectroscopic data for $7 \mathbf{b}:{ }^{1} \mathrm{H}$ NMR $\left(\mathrm{CDCl}_{3}\right) \delta 7.81-6.49(\mathrm{~m}$, $30 \mathrm{H}, \mathrm{Ph}), 5.46(\mathrm{~s}, \mathrm{Cp})$ and $3.70-3.15\left(\mathrm{~m}, 4 \mathrm{H}, \mathrm{CH}_{2} \mathrm{CH}_{2}\right) ;{ }^{31} \mathrm{P}$ $\mathrm{NMR}\left(\mathrm{CDCl}_{3}\right) \delta 77.4 ;{ }^{13} \mathrm{C} \mathrm{NMR}\left(\mathrm{CDCl}_{3}\right) \delta 351.8\left(\mathrm{t}, J_{\mathrm{C}-\mathrm{P}}=14.8\right.$, $\left.\mathrm{C}_{\alpha}\right), 166.0\left(\mathrm{C}_{\beta}\right), 135.8-126.2(\mathrm{Ph}), 114.1,113.2(2 \mathrm{CN}), 93.9$ $(\mathrm{Cp}), 85.6\left(\mathrm{C}_{\gamma}\right), 80.3\left(C(\mathrm{CN})_{2}\right)$ and $28.9\left(\mathrm{t}, J_{\mathrm{C}-\mathrm{P}}=22.9 \mathrm{~Hz}\right.$, $\left.\mathrm{PCH}_{2} \mathrm{CH}_{2} \mathrm{P}\right)$; $\mathrm{MS}\left(\mathrm{m} / \mathrm{z},{ }^{102} \mathrm{Ru}\right) 819.1\left(\mathrm{M}^{+}-\mathrm{PF}_{6}\right), 593.0\left(\mathrm{M}^{+}-\right.$ $\left.\mathrm{PF}_{6}-\mathrm{CH}=\mathrm{C}(\mathrm{CN})_{2}+\mathrm{CO}\right), 565.0\left(\mathrm{M}^{+}-\mathrm{PF}_{6}-\mathrm{CH}=\mathrm{C}(\mathrm{CN})_{2}\right)$. Calc. for $\mathrm{C}_{46} \mathrm{H}_{39} \mathrm{~F}_{6} \mathrm{~N}_{3} \mathrm{P}_{2} \mathrm{Ru}$ : C, 60.66; H, 4.32; N, 4.61. Found: C, $61.04 ; \mathrm{H}, 4.40 ; \mathrm{N}, 4.08 \%$.

$\left[\mathbf{R u C p}\left(\mathrm{PPh}_{3}\right)\left\{\mathbf{P}(\mathrm{OMe})_{3}\right\}\left\{=\mathbf{C}=\mathbf{C}(\mathbf{P h}) \mathbf{C H}_{2} \mathbf{C N}\right\}\right]$ I 8a. A Schlenk flask was charged with $\mathrm{ICH}_{2} \mathrm{CN}(0.20 \mathrm{~mL}, 1.53 \mathrm{mmol})$, complex $1 \mathrm{a}(0.20 \mathrm{~g}, 0.31 \mathrm{mmol})$ and $10 \mathrm{~mL}$ of $\mathrm{CH}_{2} \mathrm{Cl}_{2}$. The mixture was stirred at room temperature for $10 \mathrm{~min}$. The solvent was reduced to about $3 \mathrm{~mL}$ under vacuum and $20 \mathrm{~mL}$ of ether were added resulting in an orange precipitation. The mixture was filtered and the solid portion was washed with $20 \mathrm{~mL}$ of $\mathrm{n}$-pentane and $20 \mathrm{~mL}$ of diethyl ether and dried under vacuum to give $8 \mathbf{a}(0.163 \mathrm{~g}, 64.8 \%$ yield $) .{ }^{1} \mathrm{H}$ NMR $\left(\mathrm{CDCl}_{3}\right): \delta 7.49-7.06$ $(\mathrm{m}, 20 \mathrm{H}, \mathrm{Ph}), 5.54(\mathrm{~s}, \mathrm{Cp}), 3.37\left(\mathrm{~d}, 9 \mathrm{H}, J_{\mathrm{H}-\mathrm{P}}=11.1\right.$, $\left.\mathrm{P}(\mathrm{OMe})_{3}\right), 3.27$ and $3.17\left(\mathrm{dd}, \mathrm{CH}_{2} \mathrm{CN}, J_{\mathrm{H}-\mathrm{H}}=17.8 \mathrm{~Hz}\right) .{ }^{31} \mathrm{P}$ NMR $\left(\mathrm{CDCl}_{3}\right): \delta 135.4$ and $44.8\left(2 \mathrm{~d}, J_{\mathrm{P}-\mathrm{P}}=49.30 \mathrm{~Hz}\right) \cdot{ }^{13} \mathrm{C}$ NMR $\left(\mathrm{CDCl}_{3}\right): \delta 351.7$ (q, $\left.\mathrm{C}_{\alpha},{ }^{2} J_{\mathrm{C}-\mathrm{P}}=13.9,20.0\right), 133.1-126.4$ $(\mathrm{m}, \mathrm{Ph}), 118.2(\mathrm{CN}), 116.4\left(\mathrm{C}_{\beta}\right), 93.0(\mathrm{Cp}), 54.2\left(\mathrm{~d}, J_{\mathrm{C}-\mathrm{P}}=9.6\right.$ $\left.\mathrm{Hz}, \mathrm{P}(\mathrm{OMe})_{3}\right)$ and $12.3\left(\mathrm{CH}_{2} \mathrm{CN}\right)$; $\mathrm{MS}\left(\mathrm{m} / \mathrm{z},{ }^{102} \mathrm{Ru}\right): 694.1$ $\left(\mathrm{M}^{+}-\mathrm{I}\right), 553.1\left(\mathrm{M}^{+}-\mathrm{I}_{-} \mathrm{CH}_{2} \mathrm{CN}-\mathrm{CCPh}\right)$ and $429.1\left(\mathrm{M}^{+}-\right.$ $\left.\mathrm{I}-\mathrm{CH}_{2} \mathrm{CN}-\mathrm{CCPh}-\mathrm{P}(\mathrm{OMe})_{3}\right)$. Calc. for $\mathrm{C}_{36} \mathrm{H}_{36} \mathrm{INO}_{3} \mathrm{P}_{2} \mathrm{Ru}$ : C, $52.69 ; \mathrm{H}, 4.42 ; \mathrm{N}, 1.71$. Found: $\mathrm{C}, 52.89 ; \mathrm{H}, 4.36 ; \mathrm{N}, 1.65 \%$.

$\left[\mathrm{RuCp}\left(\mathrm{PPh}_{3}\right)\left\{\mathrm{P}(\mathrm{O})(\mathrm{OMe})_{2}\right\}\left\{=\mathrm{C}=\mathrm{C}(\mathrm{Ph}) \mathrm{CH}_{2} \mathrm{CN}\right\}\right]$ 9a. A Schlenk flask was charged with $\mathrm{ICH}_{2} \mathrm{CN}(0.20 \mathrm{~mL}, 1.53 \mathrm{mmol})$, complex 1a (200 mg, $0.31 \mathrm{mmol})$ and $10 \mathrm{~mL}$ of $\mathrm{CH}_{2} \mathrm{Cl}_{2}$. The mixture was heated to reflux for $1 \mathrm{~h}$. The solvent was removed under vacuum and the residue washed with hexane and dried under vacuum to give the red oily product 9a (186.9 mg, $90 \%$ yield). ${ }^{1} \mathrm{H}$ NMR $\left(\mathrm{CDCl}_{3}\right): \delta 7.50-6.86(\mathrm{~m}, 20 \mathrm{H}, \mathrm{Ph}), 5.32$ $(\mathrm{s}, \mathrm{Cp}), 3.45,3.37\left(2 \mathrm{~d}, J_{\mathrm{H}-\mathrm{H}}=12.4, \mathrm{CH}_{2} \mathrm{CN}\right), 3.31$ and 2.95 $\left(2 \mathrm{~d}, 6 \mathrm{H}, J_{\mathrm{H}-\mathrm{P}}=11.5 \mathrm{~Hz}, \mathrm{OCH}_{3}\right) .{ }^{31} \mathrm{P} \mathrm{NMR}\left(\mathrm{CDCl}_{3}\right): \delta 95.4$ and $48.1\left(2 \mathrm{~d}, J_{\mathrm{P}-\mathrm{P}}=47.0 \mathrm{~Hz}\right) \cdot{ }^{13} \mathrm{C} \mathrm{NMR}\left(\mathrm{CDCl}_{3}\right): \delta 346.2\left(\mathrm{t}, \mathrm{C}_{\alpha}\right.$, $\left.J_{\mathrm{C}-\mathrm{P}}=16.0\right), 133.5-119.7(\mathrm{~m}, \mathrm{Ph}), 117.8(\mathrm{CN}), 116.7\left(\mathrm{C}_{\beta}\right)$, $92.3(\mathrm{Cp}), 50.3\left(\mathrm{~d}, J_{\mathrm{C}-\mathrm{P}}=8.4, \mathrm{P}(\mathrm{OMe})_{3}\right), 49.8\left(\mathrm{~d}, J_{\mathrm{C}-\mathrm{P}}=9.4\right.$ $\left.\mathrm{Hz}, \mathrm{P}(\mathrm{OMe})_{3}\right)$ and $12.3\left(\mathrm{CH}_{2}\right)$; $\mathrm{MS}\left(\mathrm{m} / z,{ }^{102} \mathrm{Ru}\right): 680.1\left(\mathrm{M}^{+}+\right.$ 1), $539.1\left(\mathrm{M}^{+}-\mathrm{CH}_{2} \mathrm{CN}-\mathrm{CCPh}\right)$ and $429.1\left(\mathrm{M}^{+}-\mathrm{CH}_{2} \mathrm{CN}-\right.$ $\left.\mathrm{CCPh}-\mathrm{P}(\mathrm{O})(\mathrm{OMe})_{2}\right)$. Calc. for $\mathrm{C}_{35} \mathrm{H}_{33} \mathrm{NO}_{3} \mathrm{P}_{2} \mathrm{Ru}$ : C, 61.94; $\mathrm{H}, 4.90 ; \mathrm{N}, 2.06$. Found: C, 62.09; H, 4.72; N, 1.68\%. The complexes $\quad\left[\mathrm{RuCp}\left(\mathrm{PPh}_{3}\right)\left\{\mathrm{P}(=\mathrm{O})(\mathrm{OMe})_{2}\right\}\left\{=\mathrm{C}=\mathrm{C}(\mathrm{Ph}) \mathrm{CH}_{2} \mathrm{R}\right\}\right]$ $\left(\mathrm{R}=\mathrm{C}_{6} \mathrm{~F}_{5} 9 \mathrm{~b} ; \mathrm{Ph} 9 \mathrm{c} ; p-\mathrm{NCC}_{6} \mathrm{H}_{4} \mathrm{CN} 9 \mathrm{~d} ; p-\mathrm{F}_{3} \mathrm{CC}_{6} \mathrm{H}_{4} 9 \mathrm{e} ; 1-\mathrm{C}_{10} \mathrm{H}_{7}\right.$ 9f or $\left.\mathrm{CO}_{2} \mathrm{CH}_{3} \mathbf{9 g}\right)$ were prepared from the reaction of $\mathbf{1 a}(0.20$ g, $0.31 \mathrm{mmol}$ ) with $\mathrm{BrCH}_{2} \mathrm{C}_{6} \mathrm{~F}_{5}, \mathrm{BrCH}_{2} \mathrm{Ph}, \mathrm{BrCH}_{2}\left(\mathrm{C}_{6} \mathrm{H}_{4} \mathrm{CN}-p\right)$, $\mathrm{BrCH}_{2}\left(\mathrm{C}_{6} \mathrm{H}_{4} \mathrm{CF}_{3}-p\right), \mathrm{BrCH}_{2}\left(1-\mathrm{C}_{10} \mathrm{H}_{7}\right)$ or $\mathrm{BrCH}_{2} \mathrm{CO}_{2} \mathrm{CH}_{3}$ using a similar procedure to that for $9 \mathrm{a}$. Spectroscopic data for $9 \mathbf{b}:{ }^{1} \mathrm{H}$ NMR $\left(\mathrm{CDCl}_{3}\right) \delta 7.86-6.82(\mathrm{~m}, 20 \mathrm{H}, \mathrm{Ph}), 5.28(\mathrm{~s}, \mathrm{Cp}), 3.89$, $3.65\left(2 \mathrm{~d}, J_{\mathrm{H}-\mathrm{H}}=15.6, \mathrm{CH}_{2}\right), 3.16$ and $2.99\left(2 \mathrm{~d}, 6 \mathrm{H}, J_{\mathrm{H}-\mathrm{P}}=11.5\right.$ $\left.\mathrm{Hz}, \mathrm{OCH}_{3}\right) ;{ }^{31} \mathrm{P}$ NMR $\left(\mathrm{CDCl}_{3}\right) \delta 97.9$ and $50.4\left(2 \mathrm{~d}, J_{\mathrm{P}-\mathrm{P}}=45.5\right.$ $\mathrm{Hz}) ;{ }^{13} \mathrm{C} \mathrm{NMR}\left(\mathrm{CDCl}_{3}\right) \delta 346.4\left(\mathrm{t}, \mathrm{C}_{\alpha},{ }^{2} J_{\mathrm{C}-\mathrm{P}}=17.4\right), 146.3-125.8$ $(\mathrm{m}, \mathrm{Ph}), 123.0\left(\mathrm{C}_{\beta}\right), 92.1(\mathrm{Cp}), 50.2,49.7\left(2 \mathrm{~d}, J_{\mathrm{C}-\mathrm{P}}=7.3 \mathrm{~Hz}\right.$, $\left.\mathrm{OCH}_{3}\right)$ and 17.2 $\left(\mathrm{CH}_{2}\right)$; $\mathrm{MS}\left(\mathrm{m} / \mathrm{z},{ }^{102} \mathrm{Ru}\right) 821.1\left(\mathrm{M}^{+}+1\right), 539.1$ $\left(\mathrm{M}^{+}-\mathrm{CH}_{2} \mathrm{C}_{6} \mathrm{~F}_{5}-\mathrm{CCPh}\right)$ and $429.1\left(\mathrm{M}^{+}-\mathrm{CH}_{2} \mathrm{C}_{6} \mathrm{~F}_{5}-\mathrm{CCPh}-\mathrm{P}(\mathrm{O})-\right.$ $\left.(\mathrm{OMe})_{2}\right)$. Calc. for $\mathrm{C}_{35} \mathrm{H}_{33} \mathrm{~F}_{5} \mathrm{O}_{3} \mathrm{P}_{2} \mathrm{Ru}: \mathrm{C}, 58.61 ; \mathrm{H}, 4.06$. Found: C, 58.97; H, 3.92\%. Spectroscopic data for 9c: ${ }^{1} \mathrm{H}$ NMR $\left(\mathrm{CDCl}_{3}\right) \delta 7.76-6.89(\mathrm{~m}, 20 \mathrm{H}, \mathrm{Ph}), 5.29(\mathrm{~s}, \mathrm{Cp}), 3.84,3.68(2 \mathrm{~d}$, $\left.J_{\mathrm{H}-\mathrm{H}}=16.2, \mathrm{CH}_{2}\right), 3.30$ and $3.06\left(2 \mathrm{~d}, 6 \mathrm{H}, J_{\mathrm{H}-\mathrm{P}}=11.6 \mathrm{~Hz}\right.$, $\left.\mathrm{OCH}_{3}\right) ;{ }^{31} \mathrm{P}$ NMR $\left(\mathrm{CDCl}_{3}\right) \delta 97.5$ and $51.2\left(2 \mathrm{~d}, J_{\mathrm{P}-\mathrm{P}}=48.7 \mathrm{~Hz}\right)$; ${ }^{13} \mathrm{C} \mathrm{NMR}\left(\mathrm{CDCl}_{3}\right) \delta 347.1\left(\mathrm{t}, \mathrm{C}_{\alpha}, J_{\mathrm{C}-\mathrm{P}}=16.2,15.7\right), 133.5-119.7$ $(\mathrm{m}, \mathrm{Ph}), 117.8(\mathrm{CN}), 116.7\left(\mathrm{C}_{\beta}\right), 92.3(\mathrm{Cp}), 50.3,49.8(2 \mathrm{~d}$, $\left.J_{\mathrm{C}-\mathrm{P}}=8.93 \mathrm{~Hz}, \mathrm{OCH}_{3}\right)$ and $12.3\left(\mathrm{CH}_{2}\right)$; $\mathrm{MS}\left(\mathrm{m} / z,{ }^{102} \mathrm{Ru}\right) 732.1$ $\left(\mathrm{M}^{+}+1\right), 539.1\left(\mathrm{M}^{+}-\mathrm{CH}_{2} \mathrm{Ph}-\mathrm{CCPh}\right)$ and $429.1\left(\mathrm{M}^{+}-\mathrm{CH}_{2^{-}}\right.$ Ph-CCPh-P(O) $\left.(\mathrm{OMe})_{2}\right)$. Calc. for $\mathrm{C}_{40} \mathrm{H}_{38} \mathrm{O}_{3} \mathrm{P}_{2} \mathrm{Ru}$ : C, 65.83; $\mathrm{H}$, 5.25. Found: C, 66.01; H, 5.16\%. Spectroscopic data for 9d: ${ }^{1} \mathrm{H}$ NMR $\left(\mathrm{CDCl}_{3}\right) \delta 7.77-6.82(\mathrm{~m}, \mathrm{Ph}), 5.24(\mathrm{~s}, \mathrm{Cp}), 3.91,3.68(2 \mathrm{~d}$, $\left.J_{\mathrm{H}-\mathrm{H}}=16.4, \mathrm{CH}_{2}\right), 3.15$ and $2.98\left(2 \mathrm{~d}, 6 \mathrm{H}, J_{\mathrm{H}-\mathrm{P}}=11.2 \mathrm{~Hz}\right.$, $\left.\mathrm{OCH}_{3}\right) \cdot{ }^{31} \mathrm{P}$ NMR $\left(\mathrm{CDCl}_{3}\right) \delta 95.9,50.8\left(2 \mathrm{~d}, J_{\mathrm{P}-\mathrm{P}}=47.5 \mathrm{~Hz}\right) ;{ }^{13} \mathrm{C}$ $\operatorname{NMR}\left(\mathrm{CDCl}_{3}\right) \delta 349.4\left(\mathrm{t}, \mathrm{C}_{\alpha},{ }^{2} J_{\mathrm{C}-\mathrm{P}}=16.0\right), 147.5-118.3(\mathrm{~m}, \mathrm{Ph})$, $117.8(\mathrm{CN}), 116.7\left(\mathrm{C}_{\beta}\right), 92.1(\mathrm{Cp}), 50.3,49.9\left(2 \mathrm{~d}, J_{\mathrm{C}-\mathrm{P}}=9.0 \mathrm{~Hz}\right.$, $\left.\mathrm{OCH}_{3}\right)$ and $29.8\left(\mathrm{CH}_{2}\right)$; $\mathrm{MS}\left(\mathrm{m} / \mathrm{z},{ }^{102} \mathrm{Ru}\right) 757.1\left(\mathrm{M}^{+}+1\right), 539.1$ $\left(\mathrm{M}^{+}-\mathrm{CH}_{2} \mathrm{C}_{6} \mathrm{H}_{4} \mathrm{CN}-\mathrm{CCPh}\right)$ and $429.1\left(\mathrm{M}^{+}-\mathrm{CH}_{2} \mathrm{C}_{6} \mathrm{H}_{4} \mathrm{CN}-\right.$ CCPh-P(O)(OMe $\left.)_{2}\right)$. Calc. for $\mathrm{C}_{41} \mathrm{H}_{37} \mathrm{NO}_{3} \mathrm{P}_{2} \mathrm{Ru}$ : C, 65.24; $\mathrm{H}$, 
Table 5 Crystal data and structure refinement for $\left[\mathrm{RuCp}\left(\mathrm{PPh}_{3}\right)\left\{\mathrm{P}(\mathrm{OMe})_{3}\right\}\left\{\mathrm{C}\left[=\mathrm{C}(\mathrm{CN})_{2}\right] \mathrm{C}(\mathrm{Ph})=\mathrm{CH}(\mathrm{Ph})\right\}\right] \quad 3 \mathbf{a}, \quad\left[\mathrm{RuCp}\left\{\mathrm{P}(\mathrm{OMe})_{3}\right\}\left\{\eta^{3}-\mathrm{C}(\mathrm{CN})_{2^{-}}\right.\right.$ $\mathrm{C}(\mathrm{Ph}) \mathrm{C}=\mathrm{CH}(\mathrm{Ph})\}] 4,\left[\mathrm{RuCp}\left(\mathrm{PPh}_{3}\right)\left\{\mathrm{P}(\mathrm{O})(\mathrm{OMe})_{2}\right\}\left\{=\mathrm{C}=\mathrm{C}(\mathrm{Ph}) \mathrm{C}(\mathrm{Ph}) \mathrm{C}(\mathrm{CN})_{2}\right\}\right] 6$ and $\left[\mathrm{RuCp}\left(\mathrm{PPh}_{3}\right)\left\{\mathrm{P}(\mathrm{OMe})_{3}\right\}\left(\mathrm{COCH}_{2} \mathrm{Ph}\right)\right\} 10$

\begin{tabular}{|c|c|c|c|c|}
\hline & 3a & 4 & 6 & 10 \\
\hline Formula & $\mathrm{C}_{44} \mathrm{H}_{40} \mathrm{~N}_{2} \mathrm{O}_{3} \mathrm{P}_{2} \mathrm{Ru}$ & $\mathrm{C}_{26} \mathrm{H}_{25} \mathrm{~N}_{2} \mathrm{O}_{3} \mathrm{PRu}$ & $\mathrm{C}_{53} \mathrm{H}_{42} \mathrm{~N}_{4} \mathrm{O}_{4} \mathrm{P}_{2} \mathrm{Ru}$ & $\mathrm{C}_{34} \mathrm{H}_{36} \mathrm{O}_{4} \mathrm{P}_{2} \mathrm{Ru}$ \\
\hline & 807.82 & 546.54 & 961.95 & 935.01 \\
\hline Crystal system & Monoclinic & Monoclinic & Triclinic & Monoclinic \\
\hline Space group & $P 2_{1} / c$ & $P 2_{1} / c$ & $P \overline{1}$ & $P 2_{1} / c$ \\
\hline$T / \mathrm{K}$ & 298 & 298 & 298 & 298 \\
\hline$a / \AA ̊$ & $11.3426(14)$ & $12.1184(18)$ & $10.4298(14)$ & $18.016(3)$ \\
\hline$b / \AA ̊$ & $31.489(5)$ & $14.917(8)$ & $13.883(3)$ & $10.071(3)$ \\
\hline$c / \AA ̊$ & $11.0026(15)$ & $13.498(3)$ & $18.082(4)$ & $22.979(4)$ \\
\hline$\alpha /^{\circ}$ & & & $107.468(22)$ & \\
\hline$\beta 1^{\circ}$ & $104.206(12)$ & $92.155(14)$ & $91.791(20)$ & $105.838(14)$ \\
\hline$\gamma /{ }^{\circ}$ & & & $108.375(15)$ & \\
\hline$V / \AA^{3}$ & $3809.6(10)$ & $2438.2(14)$ & $2347.2(8)$ & $4011.1(15)$ \\
\hline$Z$ & 4 & 4 & 2 & 4 \\
\hline$\mu / \mathrm{cm}^{-1}$ & 5.262 & 7.877 & 4.392 & 7.646 \\
\hline Measured reflections & 4954 & 4271 & 8273 & 7034 \\
\hline Observed reflections & 2517 & 2169 & 4526 & 4591 \\
\hline$R, R^{\prime}$ & $0.043,0.040$ & $0.058,0.052$ & $0.044,0.035$ & $0.045,0.047$ \\
\hline
\end{tabular}

4.94; N, 1.86. Found: C, 65.53; H, 4.78; N, 1.77\%. Spectroscopic data for 9e: ${ }^{1} \mathrm{H}$ NMR $\left(\mathrm{CDCl}_{3}\right) \delta 7.76-6.89(\mathrm{~m}, \mathrm{Ph}), 5.27(\mathrm{~s}$, $\mathrm{Cp}), 3.91,3.68\left(2 \mathrm{~d}, J_{\mathrm{H}-\mathrm{H}}=16.3, \mathrm{CH}_{2}\right), 3.25$ and $3.01(2 \mathrm{~d}, 6 \mathrm{H}$, $\left.J_{\mathrm{H}-\mathrm{P}}=11.6 \mathrm{~Hz}, \mathrm{OCH}_{3}\right) ;{ }^{31} \mathrm{P} \mathrm{NMR}\left(\mathrm{CDCl}_{3}\right) \delta 96.6,50.9(2 \mathrm{~d}$, $\left.J_{\mathrm{P}-\mathrm{P}}=42.8 \mathrm{~Hz}\right) ;{ }^{13} \mathrm{C} \mathrm{NMR}\left(\mathrm{CDCl}_{3}\right) \delta 350.2\left(\mathrm{t}, \mathrm{C}_{\alpha},{ }^{2} J_{\mathrm{C}-\mathrm{P}}=17.1\right)$, $145.7-124.9\left(\mathrm{~m}, \mathrm{Ph}, \mathrm{C}_{\beta}\right), 92.1(\mathrm{Cp}), 50.4\left(\mathrm{~d}, J_{\mathrm{C}-\mathrm{P}}=8.75, \mathrm{OCH}_{3}\right)$ $49.9\left(\mathrm{~d}, J_{\mathrm{C}-\mathrm{P}}=9.21 \mathrm{~Hz}, \mathrm{OCH}_{3}\right)$ and $29.4\left(\mathrm{CH}_{2}\right) ; \mathrm{MS}\left(\mathrm{m} / \mathrm{z},{ }^{102} \mathrm{Ru}\right)$ $800.1\left(\mathrm{M}^{+}+1\right), 539.1\left(\mathrm{M}^{+}-\mathrm{CH}_{2} \mathrm{C}_{6} \mathrm{H}_{4} \mathrm{CF}_{3}-\mathrm{CCPh}\right)$ and 429.1 $\left(\mathrm{M}^{+}-\mathrm{CH}_{2} \mathrm{C}_{6} \mathrm{H}_{4} \mathrm{CF}_{3}-\mathrm{CCPh}-\mathrm{P}(\mathrm{O})(\mathrm{OMe})_{2}\right)$. Calc. for $\mathrm{C}_{35} \mathrm{H}_{33} \mathrm{~F}_{5}-$ $\mathrm{O}_{3} \mathrm{P}_{2} \mathrm{Ru}$ : C, 61.73; H, 4.68. Found: C, 61.98; H, 4.55\%. Spectroscopic data for 9f: ${ }^{1} \mathrm{H}$ NMR $\left(\mathrm{CDCl}_{3}\right) \delta 7.75-6.84(\mathrm{~m}, \mathrm{Ph}), 5.24$ (s, Cp), 3.89, $3.71\left(2 \mathrm{~d}, J_{\mathrm{H}-\mathrm{H}}=16.4, \mathrm{CH}_{2}\right), 3.23$ and $2.99(2 \mathrm{~d}, 6 \mathrm{H}$, $\left.J_{\mathrm{H}-\mathrm{P}}=11.5 \mathrm{~Hz}, \mathrm{OCH}_{3}\right) ;{ }^{31} \mathrm{P} \mathrm{NMR}\left(\mathrm{CDCl}_{3}\right) \delta 97.0$ and $50.0(2 \mathrm{~d}$, $\left.J_{\mathrm{P}-\mathrm{P}}=48.4 \mathrm{~Hz}\right) ;{ }^{13} \mathrm{C} \mathrm{NMR}\left(\mathrm{CDCl}_{3}\right) \delta 351.0\left(\mathrm{t}, \mathrm{C}_{\alpha},{ }^{2} J_{\mathrm{C}-\mathrm{P}}=16.4\right)$, 138.8-124.3 (m, Ph), $117.1\left(\mathrm{C}_{\beta}\right), 92.0(\mathrm{Cp}), 50.2,49.8(2 \mathrm{~d}$, $\left.J_{\mathrm{C}-\mathrm{P}}=9.2 \mathrm{~Hz}, \mathrm{OCH}_{3}\right)$ and $29.8\left(\mathrm{CH}_{2}\right) ; \mathrm{MS}\left(\mathrm{FAB},{ }^{102} \mathrm{Ru}\right)$ $m / z 782.1\left(\mathrm{M}^{+}+1\right), 539.1\left(\mathrm{M}^{+}-\mathrm{CH}_{2} \mathrm{C}_{10} \mathrm{H}_{7}-\mathrm{CCPh}\right)$ and 429.1 $\left(\mathrm{M}^{+}-\mathrm{CH}_{2} \mathrm{C}_{10} \mathrm{H}_{7}-\mathrm{CCPh}-\mathrm{P}(\mathrm{O})(\mathrm{OMe})_{2}\right)$. Calc. for $\mathrm{C}_{44} \mathrm{H}_{40} \mathrm{O}_{3} \mathrm{P}_{2^{-}}$ $\mathrm{Ru}: \mathrm{C}, 67.77 ; \mathrm{H}, 5.17$. Found: $\mathrm{C}, 67.95 ; \mathrm{H}, 5.06 \%$. Spectroscopic data for 9g: ${ }^{1} \mathrm{H}$ NMR $\left(\mathrm{CDCl}_{3}\right) \delta 7.84-6.88(\mathrm{~m}, 20 \mathrm{H}, \mathrm{Ph}), 5.22$ (s, Cp), 3.89, $3.75\left(2 \mathrm{~d}, J_{\mathrm{H}-\mathrm{H}}=16.5, \mathrm{CH}_{2} \mathrm{CO}_{2} \mathrm{CH}_{3}\right), 3.17$ and 2.90 $\left(2 \mathrm{~d}, 6 \mathrm{H}, J_{\mathrm{H}-\mathrm{P}}=11.6 \mathrm{~Hz}, \mathrm{OCH}_{3}\right) ;{ }^{31} \mathrm{P} \mathrm{NMR}\left(\mathrm{CDCl}_{3}\right) \delta 96.9$ and $50.2\left(2 \mathrm{~d}, J_{\mathrm{P}-\mathrm{P}}=49.1 \mathrm{~Hz}\right) ;{ }^{13} \mathrm{C}$ NMR $\left(\mathrm{CDCl}_{3}\right) \delta 350.8\left(\mathrm{t}, \mathrm{C}_{\alpha}\right.$, $\left.{ }^{2} J_{\mathrm{C}-\mathrm{P}}=15.6\right), 173.1\left(\mathrm{CO}_{2} \mathrm{CH}_{3}\right), 135.5-124.8(\mathrm{~m}, \mathrm{Ph}), 121.0\left(\mathrm{C}_{\beta}\right)$, $92.1(\mathrm{Cp}), 50.0,49.6\left(2 \mathrm{~d}, J_{\mathrm{C}-\mathrm{P}}=8.7 \mathrm{~Hz}, \mathrm{OCH}_{3}\right), 51.5\left(\mathrm{CH}_{2}\right.$ $\left.\mathrm{CO}_{2} \mathrm{CH}_{3}\right)$ and $28.7\left(\mathrm{CO}_{2} \mathrm{CH}_{3}\right) ; \mathrm{MS}\left(\mathrm{m} / \mathrm{z},{ }^{102} \mathrm{Ru}\right) 712.1\left(\mathrm{M}^{+}+1\right)$, $539.1\left(\mathrm{M}^{+}-\mathrm{CH}_{2} \mathrm{CO}_{2} \mathrm{CH}_{3}-\mathrm{CCPh}\right)$ and $429.1\left(\mathrm{M}^{+}-\mathrm{CH}_{2} \mathrm{CO}_{2}^{-}\right.$ $\left.\mathrm{CH}_{3}-\mathrm{CCPh}-\mathrm{P}(\mathrm{O})(\mathrm{OMe})_{2}\right)$. Calc. for $\mathrm{C}_{36} \mathrm{H}_{36} \mathrm{O}_{5} \mathrm{P}_{2} \mathrm{Ru}: \mathrm{C}, 60.75 ; \mathrm{H}$, 5.10. Found: $\mathrm{C}, 61.03 ; \mathrm{H}, 5.02 \%$.

[RuCp( $\left.\left(\mathbf{P P h}_{3}\right)\left\{\mathbf{P}(\mathrm{OMe})_{3}\right\}\left\{\mathbf{C O C H}_{2} \mathbf{P h}\right)\right]$ 10. A Schlenk flask was charged with $\mathrm{ICH}_{2} \mathrm{CN}(0.20 \mathrm{~mL}, 1.53 \mathrm{mmol})$, complex 1a (200 mg, $0.31 \mathrm{mmol}), \mathrm{NH}_{4} \mathrm{PF}_{6}(74.8 \mathrm{mg}, 0.459 \mathrm{mmol})$, and 20 $\mathrm{mL}$ of $\mathrm{CH}_{2} \mathrm{Cl}_{2}$. The solution was stirred at room temperature for $24 \mathrm{~h}$. Then the solvent was removed under vacuum and the residue washed with $20 \times 2 \mathrm{~mL}$ of hexane and $20 \times 2 \mathrm{~mL}$ of ether to give the pale yellow product $\mathbf{1 0}(168.3 \mathrm{mg}, 82 \%$ yield $)$. ${ }^{1} \mathrm{H}$ NMR $\left(\mathrm{CD}_{3} \mathrm{COCD}_{3}\right): \delta 7.65-6.80(\mathrm{~m}, 20 \mathrm{H}, \mathrm{Ph}), 5.27(\mathrm{~s}, \mathrm{Cp})$, $4.77,4.68\left(\mathrm{dd}, J_{\mathrm{H}-\mathrm{H}}=17.65, \mathrm{CH}_{2}\right)$ and $3.53\left(\mathrm{~d}, 9 \mathrm{H}, J_{\mathrm{H}-\mathrm{P}}=10.87\right.$ $\left.\mathrm{Hz}, \mathrm{P}(\mathrm{OMe})_{3}\right) \cdot{ }^{31} \mathrm{P}$ NMR $\left(\mathrm{CD}_{3} \mathrm{COCD}_{3}\right): \delta 154.2$ and $55.8(2 \mathrm{~d}$, $\left.J_{\mathrm{P}-\mathrm{P}}=61.1 \mathrm{~Hz}\right) ; \mathrm{MS}\left(\mathrm{m} / \mathrm{z},{ }^{102} \mathrm{Ru}\right) 672.1\left(\mathrm{M}^{+}\right), 553.1\left(\mathrm{M}^{+}-\right.$ $\left.\mathrm{COCH}_{2} \mathrm{Ph}\right)$ and $429.1\left(\mathrm{M}^{+}-\mathrm{COCH}_{2} \mathrm{Ph}-\mathrm{P}(\mathrm{OMe})_{3}\right)$.

\section{X-Ray analysis of complex 3a}

Single crystals of complex 3a were grown as mentioned above. A single crystal was mounted on an Enraf-Nonius CAD4 diffractometer. Cell constant and other pertinent data are collected in Table 5. The NRCC structure determination package ${ }^{21}$ was used for crystallographic computations. Merging of equiv- alent and duplicate reflections gave a total of 4954 unique data, from which 2517 were considered observed $(I>2 \sigma(I))$. The structure was solved by the heavy atom method then refined via standard least-squares and Fourier-difference techniques. The analytical forms of the scattering factor tables for the neutral atoms were used. ${ }^{23}$ Final refinement converged smoothly to values of $R=0.043$ and $R^{\prime}=0.040$. The procedures for the structure determination of $\mathbf{4 , 6}$, and 10 were similar.

CCDC reference number 186/1698.

See http://www.rsc.org/suppdata/dt/1999/4223/ for crystallographic files in .cif format.

\section{Acknowledgements}

We are grateful for support of this work by the National Science Council, Taiwan, Republic of China.

\section{References}

1 W. Beck, B. Niemer and M. Wieser, Angew. Chem., Int. Ed. Engl., 1993, 32, 923; L. S. Hegedus, in Organometallics in Synthesis, ed. M. Schlosser, Wiley, New York, 1994, p. 383; T. Bartik, B. Bartik, M. Brady, R. Dembinski and J. A. Gladysz, Angew. Chem., 1996, 3S 414; P. C. Ting, Y. C. Lin, G. H. Lee, M. C. Cheng and Y. Wang, J. Am. Chem. Soc., 1996, 118, 6433.

2 L. K. Myers, C. Langhoff and M. B. Thompson, J. Am. Chem. Soc., 1992, 114, 7560; T. Kaharu, H. Matsubara and S. Takahashi, J. Mater. Chem., 1992, 2, 43; O. Lavastre, M. Even, P. H. Dixneuf, A. Pacreau and J. P. Vairon, Organometallics, 1996, 15, 1530; I. Y. Wu, J. T. Lin, J. Luo, S. S. Sun, C. S. Lee, K. J. Lin, C. Tsai, C. C. Hsu and J. L. Lin, Organometallics, 1997, 16, 2038.

3 H. Hoberg and B. W. Oster, J. Organomet. Chem., 1983, 252, 359.

4 M. I. Bruce, T. W. Hambley, M. J. Leddell, M. R. Snow, A. G. Swincer and R. T. Tiekink, Organometallics, 1990, 9, 96.

5 I. P. Selegue, J. Am. Chem. Soc., 1982, 104, 119.

6 A. Davison and J. P. Solar, J. Organomet. Chem., 1979, 166, C13; M. I. Bruce, T. W. Hambley, M. R. Snow and A. G. Swincer, Organometallics, 1985, 4, 501 .

7 P. Hong, K. Sonogashira and N. Hagihara, J. Organomet. Chem., 1981, 219, 363; A. G. M. Barrett, N. E. Carpenter, J. Mortier and M. Sabat, Organometallics, 1990, 9, 151.

8 R. Criegee and K. Noll, Leibigs Ann. Chem., 1959, 627, 1; R. Criegee, D. Seebach, R. E. Winter, B. Borretzen and H. A. Brune, Chem. Ber., 1965, 98, 2339.

9 R. B. Woodward and R. Hoffmann, J. Am. Chem. Soc., 1965, 87, 4388 .

10 J. I. Brauman and D. M. Golden, J. Am. Chem. Soc., 1968, 90, 1920. 11 J. Breulet and H. F. Schaefer, J. Am. Chem. Soc., 1984, 106, 1221.

12 F. Minzani, C. Pelizzi and G. Predieri, J. Organomet. Chem., 1982, 231, C6; M. I. Bruce, M. J. Liddell, M. R. Snow and E. R. T. Tiekink, Organometallics, 1988, 7, 343.

13 M. I. Bruce, D. N. Duffy, M. J. Liddell, M. R. Snow and R. T. Tiekink, Organometallics, 1992, 11, 1527.

14 M. I. Bruce, P. A. Humphrey, M. R. Snow, A. G. Swincer and R. T. Tiekink, J. Organomet. Chem., 1986, 303, 417. 
15 C. W. Chang, Y. C. Lin, G. H. Lee, S. L. Huang and Y. Wang, Organometallics, 1998, 17, 2534.

16 C. K. Johnson, ORTEP II, Report ORNL-5138, Oak Ridge National Laboratory, Oak Ridge, TN, 1976

17 T. B. Brill and S. Landon, Chem. Rev., 1984, 84, 577; H. Nakazawa and K. Miyoshi, Trends Organomet. Chem., 1994, 1, 295.

18 A. G. Maki and R. A. Toth, J. Mol. Spectrosc., 1965, 17, 136.

19 D. L. Allen, V. G. Gibson, M. L. Green, T. F. Skinner, J. Bashikin and P. D. Grebenik, J. Chem. Soc., Chem. Commun., 1985, 895; G. Consiglio and F. Morandini, Chem. Rev., 1987, 87, 761.
20 M. I. Bruce and A. G. Swincer, Aust. J. Chem., 1980, 33, 1471.

21 K. Schulze, B. Schulze and C. Richter, Chem. Abstr., 1989, 111, $6889 d$.

22 E. J. Gabe, F. L. Lee and Y. Lepage, in Crystallographic Computing 3, eds. G. M. Sheldrick, C. Kruger and R. Goddard, Clarendon Press, Oxford, 1985, p. 167.

23 International Tables for X-ray Crystallography, Reidel, Dordrecht, Boston, 1974, vol. IV.

Paper 9/05788I 